\title{
Human health implications of organic food and organic agriculture: a comprehensive review
}

\author{
Axel Mie ${ }^{1,2^{*}}\left(\mathbb{D}\right.$, Helle Raun Andersen ${ }^{3}$, Stefan Gunnarsson ${ }^{4}$, Johannes Kahl ${ }^{5}$, Emmanuelle Kesse-Guyot ${ }^{6}$, \\ Ewa Rembiałkowska ${ }^{7}$, Gianluca Quaglio ${ }^{8}$ and Philippe Grandjean ${ }^{3,9}$
}

\begin{abstract}
This review summarises existing evidence on the impact of organic food on human health. It compares organic vs. conventional food production with respect to parameters important to human health and discusses the potential impact of organic management practices with an emphasis on EU conditions. Organic food consumption may reduce the risk of allergic disease and of overweight and obesity, but the evidence is not conclusive due to likely residual confounding, as consumers of organic food tend to have healthier lifestyles overall. However, animal experiments suggest that identically composed feed from organic or conventional production impacts in different ways on growth and development. In organic agriculture, the use of pesticides is restricted, while residues in conventional fruits and vegetables constitute the main source of human pesticide exposures. Epidemiological studies have reported adverse effects of certain pesticides on children's cognitive development at current levels of exposure, but these data have so far not been applied in formal risk assessments of individual pesticides.

Differences in the composition between organic and conventional crops are limited, such as a modestly higher content of phenolic compounds in organic fruit and vegetables, and likely also a lower content of cadmium in organic cereal crops. Organic dairy products, and perhaps also meats, have a higher content of omega-3 fatty acids compared to conventional products. However, these differences are likely of marginal nutritional significance. Of greater concern is the prevalent use of antibiotics in conventional animal production as a key driver of antibiotic resistance in society; antibiotic use is less intensive in organic production. Overall, this review emphasises several documented and likely human health benefits associated with organic food production, and application of such production methods is likely to be beneficial within conventional agriculture, e.g., in integrated pest management.
\end{abstract}

Keywords: Agricultural crops, Antibiotic resistance, Food safety, Nutrients, Organic food, Pesticide residues

\section{Background}

The long-term goal of developing sustainable food systems is considered a high priority by several intergovernmental organisations [1-3]. Different agricultural management systems may have an impact on the sustainability of food systems, as they may affect human health as well as animal wellbeing, food security and environmental sustainability. In this paper, we review the

\footnotetext{
* Correspondence: axel.mie@ki.se

'Karolinska Institutet, Department of Clinical Science and Education,

Södersjukhuset, 11883 Stockholm, Sweden

${ }^{2}$ Swedish University of Agricultural Sciences (SLU), Centre for Organic Food and Farming (EPOK), Ultuna, Sweden

Full list of author information is available at the end of the article
}

available evidence on links between farming system (conventional vs organic) and human health.

Food production methods are not always easy to classify. This complexity stems from not only the number and varying forms of conventional and organic agricultural systems but also resulting from the overlap of these systems. In this paper, we use the term "conventional agriculture" as the predominant type of intensive agriculture in the European Union (EU), typically with high inputs of synthetic pesticides and mineral fertilisers, and a high proportion of conventionally-produced concentrate feed in animal production. Conversely, "organic agriculture" is in accordance with EU regulations or similar standards for organic production, comprising the use of organic 
fertilisers such as farmyard and green manure, a predominant reliance on ecosystem services and non-chemical measures for pest prevention and control and livestock access to open air and roughage feed.

In 2015, over 50.9 million hectares, in 179 countries around the world, were cultivated organically, including areas in conversion [4]. The area under organic management (fully converted and in-conversion) has increased during the last decades in the European Union, where binding standards for organic production have been developed $[5,6]$. In the 28 countries forming the EU today, the fraction of organically cultivated land of total agricultural area has been steadily increasing over the last three decades. $0.1 \%, 0.6 \%, 3.6 \%$, and $6.2 \%$ of agricultural land were organic in $1985,1995,2005$, and 2015, respectively, equalling 11.2 million ha in 2015 [7-9]. In 7 EU Member States, at least $10 \%$ of the agricultural land is organic [7]. In 2003, 125,000 farms in the EU were active in organic agriculture, a number that increased to 185,000 in 2013 [10]. Between 2006 and 2015, the organic retail market has grown by $107 \%$ in the EU, to $€ 27.1$ billion [7].

This review details the science on the effects of organic food and organic food production on human health and includes

(1) studies that directly address such effects in epidemiological studies and clinical trials.

(2)animal and in vitro studies that evaluate biological effects of organic compared to conventional feed and food.

Focusing on narrower aspects of production, we then discuss the impact of the production system on

(3) plant protection, pesticide exposure, and effects of pesticides on human health,

(4) plant nutrition, the composition of crops and the relevance for human health,

(5) animal feeding regimens, effects on the composition of animal foods and the relevance for human health.

(6) animal health and well-being, the use of antibiotics in animal production, its role in the development of antibiotic resistance, and consequences of antibiotic resistance for public health.

In the discussion, we widen the perspective from production system to food system and sustainable diets and address the interplay of agricultural production system and individual food choices. The consequences of these aspects on public health are briefly discussed.

Due to a limited evidence base, minimal importance, lack of a plausible link between production system and health, or due to lack of relevance in the European Union, we do not or only briefly touch upon
(1) singular food safety events such as outbreaks of diseases that are not clearly caused by the production system (hygiene regulations for plant production and for animal slaughtering and processing are for the most part identical for organic and conventional agriculture) or fraudulent introduction of contaminated feed into the feed market

(2)historic events and historic sources of exposure, such as the BSE crisis caused by the now-banned practice of feeding cattle with meat and bone meal from cattle, or continuing effects of the historic use of DDT, now banned in all agricultural contexts globally

(3) contaminants from food packaging

(4) aspects of food processing, such as food additives

(5) the presence of mycotoxins in consequence of postharvest storage and processing which is governed chiefly by moisture and temperature in storage

(6) the use of growth hormones in animal production, which is not permitted in the EU but in several other countries

Furthermore, aspects of environmental sustainability, such as biodiversity and greenhouse gas emissions, may also be affected by the agricultural production system $[11,12]$ and may affect human health via food security $[13,14]$. While these indirect links are outside the scope of this review, we briefly touch on them in the discussion. Also, the focus of this article is on public health, not on occupational health of agricultural workers or local residents, although these issues are considered as part of the epidemiological evidence on pesticide effects. While agricultural standards vary between countries and regions, we maintain a global perspective when appropriate and otherwise focus on the European perspective.

The literature search for this review was carried out at first using the PubMed and Web of Science databases, while applying "organic food" or "organic agriculture" along with the most relevant keywords, through to the end of 2016 (more recent references were included, when relevant, although they were not identified through the systematic search). We made use of existing systematic reviews and meta-analyses when possible. In some cases, where scientific literature is scarce, we included grey literature e.g. from authorities and intergovernmental organisations. We also considered references cited in the sources located.

\section{Association between organic food consumption and health: Findings from human studies}

A growing literature is aiming at characterizing individual lifestyles, motivations and dietary patterns in regard to organic food consumption, which is generally defined 
from responses obtained from food frequency questionnaires [15-23]. Still, current research on the role of organic food consumption in human health is scarce, as compared to other nutritional epidemiology topics. In particular, long-term interventional studies aiming to identify potential links between organic food consumption and health are lacking, mainly due to high costs. Prospective cohort studies constitute a feasible way of examining such relationships, although compliance assessment is challenging. Considering a lack of biomarkers of exposure, the evaluation of the exposure, i.e. organic food consumption, will necessarily be based on selfreported data that may be prone to measurement error.

Some recent reviews have compiled the findings [24-26] from clinical studies addressing the association between consumption of organic food and health. These studies are scant and generally based on very small populations and short durations, thus limiting statistical power and the possibility to identify long-term effects. Smith-Spangler et al. [25] summarised the evidence from clinical studies that overall no clinically significant differences in biomarkers related to health or to nutritional status between participants consuming organic food compared to controls consuming conventional food. Among studies of nutrient intakes, the OrgTrace cross-over intervention study of 33 males, the plant-based fraction of the diets was produced in controlled field trials, but 12 days of intervention did not reveal any effect of the production system on the overall intake or bioavailability of zinc and copper, or plasma status of carotenoids [27, 28].

In observational studies, a specific challenge is the fact that consumers who regularly buy organic food tend to choose more vegetables, fruit, wholegrain products and less meat, and tend to have overall healthier dietary patterns $[18,29]$. Each of these dietary characteristics is associated with a decreased risk for mortality from or incidence of certain chronic diseases [30-36]. Consumers who regularly buy organic food are also more physically active and less likely to smoke [18, 19, 37]. Depending on the outcome of interest, associations between organic vs conventional food consumption and health outcome therefore need to be carefully adjusted for differences in dietary quality and lifestyle factors, and the likely presence of residual confounding needs to be considered. In children, several studies have reported a lower prevalence of allergy and/or atopic disease in families with a lifestyle comprising the preference of organic food [38-44]. However, organic food consumption is part of a broader lifestyle in most of these studies and associated with other lifestyle factors. Thus, in the Koala birth cohort of 2700 mothers and babies from the Netherlands [39], exclusive consumption of organic dairy products during pregnancy and during infancy was associated with a $36 \%$ reduction in the risk of eczema at age 2 years. In this cohort, the preference of organic food was associated with a higher content of ruminant fatty acids in breast milk [40], which in turn was associated with a lower odds ratio for parent-reported eczema until age $2 \mathrm{y}$ [45].

In the MOBA birth cohort study of 28,000 mothers and their offspring, women reporting a frequent consumption of organic vegetables during pregnancy exhibited a reduction in risk of pre-eclampsia [29] $(\mathrm{OR}=0.79,95 \%$ CI 0.62 to 0.99$)$. No significant association was observed for overall organic food consumption, or five other food groups, and pre-eclampsia.

The first prospective study investigating weight change over time according to the level of organic food consumption included 62,000 participants of the NutriNet-Santé study. BMI increase over time was lower among high consumers of organic food compared to low consumers (mean difference as \% of baseline BMI $=-0.16$, 95\% Confidence Interval (CI): $-0.32 ;-0.01)$. A 31\% (95\% CI: $18 \%$; $42 \%)$ reduction in risk of obesity was observed among high consumers of organic food compared to low consumers. Two separate strategies were chosen to properly adjust for confounders [46]. This paper thus confirms earlier cross-sectional analyses from the same study [18].

In regard to chronic diseases, the number of studies is limited. In the Nutrinet-Santé study, organic food consumers (occasional and regular), as compared to nonconsumers, exhibited a lower incidence of hypertension, type 2 diabetes, hypercholesterolemia (in both males and females), and cardiovascular disease (in men) [47] but more frequently declared a history of cancer. Inherent to cross-sectional studies, reverse causation cannot be excluded; for example, a cancer diagnosis by itself may lead to positive dietary changes [48].

Only one prospective cohort study conducted in adults addressed the effect of organic food consumption on cancer incidence. Among 623,080 middle-aged UK women, the association between organic food consumption and the risk of cancer was estimated during a follow-up period of $9.3 \mathrm{y}$. Participants reported their organic food consumption through a frequency question as never, sometimes, or usually/always. The overall risk of cancer was not associated with organic food consumption, but a significant reduction in risk of nonHodgkin lymphoma was observed in participants who usually/always consume organic food compared to people who never consume organic food $(R R=0.79$, 95\% CI: 0.65; 0.96) [37].

In conclusion, the link between organic food consumption and health remains insufficiently documented in epidemiological studies. Thus, well-designed studies characterized by prospective design, long-term duration and sufficient sample size permitting high statistical 
power are needed. These must include detailed and accurate data especially for exposure assessment concerning dietary consumption and sources (i.e. conventional or organic).

\section{Experimental in vitro and animal studies In vitro studies}

The focus on single plant components in the comparison of crops from organic and conventional production, as discussed further below, disregards the fact that compounds in food do not exist and act separately, but in their natural context [49]. In vitro studies of effects of entire foods in biological systems such as cell lines can therefore potentially point at effects that cannot be predicted from chemical analyses of foods, although a limitation is that most cells in humans are not in direct contact with food or food extracts.

Two studies have investigated the effect of organic and conventional crop cultivation on cancer cell lines, both using crops produced under well-documented agricultural practices and with several agricultural and biological replicates. In the first study extracts from organically grown strawberries exhibited stronger antiproliferative activity against one colon and one breast cancer cell line, compared to the conventionally produced strawberries [50]. In the second study [51] the extracts of organic naturally fermented beetroot juices induced lower levels of early apoptosis and higher levels of late apoptosis and necrosis in a gastric cancer cell line, compared to the conventional extracts. Both studies thus demonstrated notable differences in the biological activity of organic vs. conventionally produced crop extracts in vitro, which should inspire further research. However, neither of these studies allows for the distinction of a selective antiproliferative effect on cancer cells, and general cell toxicity. Therefore it cannot be determined which of the organic or conventional food extracts, if any, had the preferable biological activity in terms of human health.

\section{Animal studies of health effects}

Considering the difficulties of performing long-term dietary intervention studies in humans, animal studies offer some potential of studying long-term health effects of foods in vivo. However, extrapolation of the results from animal studies to humans is not straightforward. Studies in this field started almost 100 years ago. A review of a large number of studies [52] concluded that positive effects of organic feed on animal health are possible, but further research is necessary to confirm these findings. Here we focus on the main health aspects.
In one of the best-designed animal studies, the second generation chickens receiving the conventionally grown feed demonstrated a faster growth rate. However, after an immune challenge, chickens receiving organic feed recovered more quickly [53]. This resistance to the challenge has been interpreted as a sign of better health $[54,55]$.

In one carefully conducted crop production experiment, followed by a rat feeding trial, the production system had an apparent effect on plasma-IgG concentrations but not on other markers of nutritional or immune status [56]. A two-generational rat study based on feed grown in a factorial design (fertilisation $\mathrm{x}$ plant protection) of organic and conventional practices revealed that the production system had an effect on several physiological, endocrine and immune parameters in the offspring [57]. Most of the effects identified were related to the fertilisation regimen. None of these studies found that any of the feed production systems was more supportive of animal health.

Several other studies, mostly in rats, have reported some effect of the feed production system on immune system parameters [57-60]. However, the direct relevance of these findings for human health is uncertain.

Collectively, in vitro and animal studies have demonstrated that the crop production system does have an impact on certain aspects of cell life, the immune system, and overall growth and development. However, the direct relevance of these findings for human health is unclear. On the other hand, these studies may provide plausibility to potential effects of conventional and organic foods on human health. Still, most of the outcomes observed in animal studies have not been examined in humans so far.

\section{Pesticides \\ Plant protection in organic and conventional agriculture}

Plant protection in conventional agriculture is largely dependent on the use of synthetic pesticides. Conversely, organic farming generally relies on prevention and biological means for plant protection, such as crop rotation, intercropping, resistant varieties, biological control employing natural enemies, hygiene practices and other measures [61-64]. Yet, certain pesticides are approved for use in organic agriculture. In the EU, pesticides (in this context, more specifically chemical plant-protection products; micro- and macrobiological agents are excluded from this discussion due to their low relevance for human health) are approved after an extensive evaluation, including a range of toxicological tests in animal studies [65]. Acceptable residue concentrations in food are calculated from the same documentation and from the expected concentrations in accordance with 
approved uses of the pesticides. Currently, 385 substances are authorised as pesticides in the EU (Table 1). Of these, 26 are also approved for use in organic agriculture $[6,66]$ as evaluated in accordance with the same legal framework.

Most of the pesticides approved for organic agriculture are of comparatively low toxicological concern for consumers because they are not associated with any identified toxicity (e.g. spearmint oil, quartz sand), because they are part of a normal diet or constitute human nutrients (e.g. iron, potassium bicarbonate, rapeseed oil) or because they are approved for use in insect traps only and therefore have a negligible risk of entering the food chain (i.e. the synthetic pyrethroids lambda-cyhalothrin and deltamethrin, and pheromones). Two notable exceptions are the pyrethrins and copper. Pyrethrins, a plant extract from Chrysanthemum cinerariaefolium, share the same mechanism of action as the synthetic pyrethroid insecticides, but are less stable. Copper is an essential nutrient for plants, animals and humans, although toxic at high intakes and of ecotoxicological concern due to toxicity to aquatic organisms.

Plant protection practices developed in and for organic agriculture may be of benefit to the entire agricultural system [67-70]. This is of specific value for the transition towards sustainable use of pesticides in the EU, which has a strong emphasis on nonchemical plant protection measures including prevention and biological agents [63, 64]. Further, steam treatment of cereal seeds for the prevention of fungal diseases (http://thermoseed.se/) has been developed driven by the needs of organic agriculture as an alternative to chemical seed treatments [71, 72]. These methods are now also being marketed for

Table 1 Active substances approved in the EU and important toxicological properties according to risk assessments by EFSA. Data compiled from the EU pesticides database [66] and from Commission Regulation 889/2008 (consolidated version 2016-11-07) Annex II Sections 1-3 [6]

\begin{tabular}{|c|c|c|}
\hline & Approved in EU agriculture ${ }^{a}$ & Also approved in EU organic agriculture ${ }^{a}$ \\
\hline Total number of EU-approved active substances (+ basic substances ${ }^{\mathrm{b}}$ ) & $385(+15)$ & $26(+10)$ \\
\hline \multicolumn{3}{|l|}{ Of these: } \\
\hline Any identified toxicity ${ }^{c}$ & 340 & 10 \\
\hline \multicolumn{3}{|l|}{ Classified as ${ }^{d}$} \\
\hline Acutely toxic class $1+2+3+4$, total $^{\mathrm{e}}$ & $5+17+26+76,99$ & $0+0+2+2,3^{f}$ \\
\hline Carcinogenicity category $2^{g}$ & 27 & 0 \\
\hline Germ cell mutagenicity category $2^{\mathrm{h}}$ & 2 & 0 \\
\hline Reproductive toxicity category $1 B+2^{i}$ & $5+21$ & 0 \\
\hline \multicolumn{3}{|l|}{ Candidate for substitution ${ }^{j}$} \\
\hline Low ADI/ARfD/AOEL & 19 & 0 \\
\hline Two PBT criteria fulfilled ${ }^{k}$ & 54 & $1^{\prime}$ \\
\hline Reproductive toxicity $1 \mathrm{~B}^{\mathrm{i}}$ & 5 & 0 \\
\hline Endocrine disrupting properties & 5 & 0 \\
\hline
\end{tabular}

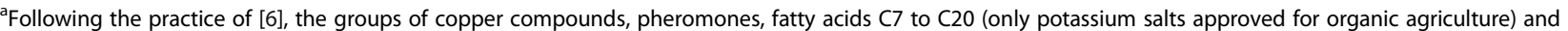
paraffin oils are counted as one substance per group. In deviation from [6], plant oils are counted as four substances due to different toxicological properties. Microorganisms (biological plant protection products) are not included

${ }^{b}$ Basic substances are compounds with a low risk profile that are useful in plant protection but primarily have other uses. Basic substances have a different approval procedure compared to active substances in the EU

'Identified chronic (ADI - acceptable daily intake assigned) and/or acute toxicity (ARfD - acute reference dose assigned) and/or an identified acceptable operator exposure level (AOEL)

"According to Regulation 1272/2008. Only classifications that relate to human health effects and to at least one of the criteria for "candidates for substitution" are included in the table (e.g. skin sensitisation not included). These classifications relate to a compound's intrinsic hazardous properties, irrespective of its use and exposure pattern. Classifications without any compound are not included in this table (e.g. carcinogenicity class $1 \mathrm{~A}+\mathrm{B}$ )

${ }^{\text {e}}$ Class 1 referring to the highest acute toxicity. Some substances have multiple classifications for different endpoints, therefore the total number of compounds is lower than the sum

${ }^{f}$ Pyrethrins, extract from Chrysanthemum cinerariaefolium, are classified as acutely toxic class 4. In addition, two acutely toxic synthetic pyrethroids are approved for use in certain insect traps in organic agriculture: lambda-cyhalothrin (class $3+4$ ) and deltamethrin (class 3 )

9Category 2: "Suspected human carcinogens". (Category 1A/B: known/presumed to have carcinogenic potential for humans. No substances in this class)

hCategory 2: "Substances which cause concern for humans owing to the possibility that they may induce heritable mutations in the germ cells of humans". (Category 1A/B: "Substances known to/to be regarded as if they induce heritable mutations in the germ cells of humans". No substances in this class)

'1B: "Presumed human reproductive toxicant", 2: "Suspected human reproductive toxicant". (1A: "Known human reproductive toxicant". No substances in this class)

${ }^{\mathrm{j}}$ Refers to approved substances that should be replaced when less hazardous substances/products are available. The criteria "Carcinogenic $1 \mathrm{~A} / 1 \mathrm{~B}$ " (no compound), "Nature of critical effects" (no compound, no criteria defined) and "Non-active isomers" (two compounds, none approved in organic agriculture) are omitted from this table

kPBT criteria: persistent, bioaccumulative and toxic according to criteria specified in [65]

'Copper. PBT classification based on accumulation in freshwater/estuarine sediment (P) and toxicity to algae and daphnia (T) 
conventional agriculture, specifically for integrated pest management (IPM) [73].

\section{Pesticide use - Exposure of consumers and producers}

One main advantage of organic food production is the restricted use of synthetic pesticides [5, 6], which leads to low residue levels in foods and thus lower pesticide exposure for consumers. It also reduces the occupational exposure of farm workers to pesticides and drift exposures of rural populations. On average over the last three available years, EFSA reports pesticide residues below Maximum Residue Levels (MRL) in 43.7\% of all and $13.8 \%$ of organic food samples. MRLs reflect the approved use of a pesticide rather than the toxicological relevance of the residue. There are no separate MRLs for organic products. A total of $2.8 \%$ of all and $0.9 \%$ of organic samples exceeded the MRL, which may be due to high residue levels or due to low levels but unapproved use of a particular pesticide on a particular crop [74-76]. Of higher toxicological relevance are risk assessments, i.e. expected exposure in relation to toxicological reference values. On average $1.5 \%$ of the samples were calculated to exceed the acute reference dose (ARfD) for any of the considered dietary scenarios, with the organophosphate chlorpyrifos accounting for approximately half of these cases and azole fungicides (imazalil, prochloraz, and thiabendazole) for approximately $15 \%$. None $(0 \%)$ of the organic samples exceeded the ARfD [74]. Residues of more than one pesticide were found in approximately $25 \%$ of the samples but calculations of cumulative risks were not included in the reports [74-76].

The only cumulative chronic risk assessment comparing organic and conventional products known to us has been performed in Sweden. Using the hazard index (HI) method [77], adults consuming $500 \mathrm{~g}$ of fruit, vegetables and berries per day in average proportions had a calculated $\mathrm{HI}$ of $0.15,0.021$ and 0.0003 , under the assumption of imported conventional, domestic conventional, and organic products, respectively [78]. This indicates an at least 70 times lower exposure weighted by toxicity for a diet based on organic foods. There are several routes by which pesticides not approved for use in organic agriculture may contaminate organic products, including spray drift or volatilisation from neighbouring fields, fraudulent use, contamination during transport and storage in vessels or storages where previously conventional products have been contained, and mislabelling by intention or mistake. Overall, however, current systems for the certification and control of organic products ensure a low level of pesticide contamination as indicated by chronic and acute risks above, although they still can be improved [79].
The general population's exposure to several pesticides can be measured by analysing blood and urine samples, as is routinely done in the US [80] although not yet in Europe. However, a few scattered European studies from France [81-83], Germany [84], the Netherlands [85], Spain [86], Belgium [87], Poland [88] and Denmark [89] have shown that EU citizens are commonly exposed to organophosphate and pyrethroid insecticides. A general observation has been higher urinary concentrations of pesticide metabolites in children compared to adults, most likely reflecting children's higher food intake in relation to body weight and maybe also more exposureprone behaviours. The urinary concentrations of generic metabolites of organophosphates (dialkyl phosphates, DAPs) and pyrethroids (3-phenoxybenzoic acid, 3-PBA) found in most of the European studies were similar to or higher than in the US studies. Although urinary metabolite concentration might overestimate the exposure to the parent compounds, due to ingestion of preformed metabolites in food items, several studies have reported associations between urinary metabolite concentrations and neurobehavioral deficits as described below. Besides, the metabolites are not always less toxic than the parent compounds [90].

For the general population, pesticide residues in food constitute the main source of exposure for the general population. This has been illustrated in intervention studies where the urinary excretion of pesticides was markedly reduced after 1 week of limiting consumption to organic food [91-93]. Similar conclusions emerged from studies investigating associations between urinary concentrations of pesticides and questionnaire information on food intake, frequency of different foodstuffs and organic food choices. Thus a high intake of fruit and vegetables is positively correlated with pesticide excretion [94], and frequent consumption of organic produce is associated with lower urinary pesticide concentration [95].

\section{Pesticide exposure and health effects}

The regulatory risk assessment of pesticides currently practised in the EU is comprehensive, as a large number of toxicological effects are addressed in animal and other experimental studies. Nonetheless, there are concerns that this risk assessment is inadequate at addressing mixed exposures, specifically for carcinogenic effects [96] as well as endocrine-disrupting effects $[97,98]$ and neurotoxicity [99]. Furthermore, there are concerns that test protocols lag behind independent science [100], studies from independent science are not fully considered [101] and data gaps are accepted too readily [102]. These concerns primarily relate to effects of chronic exposure and to chronic effects of acute exposure, which are generally more difficult to discover than acute 
effects. Most studies rely on urinary excretion of pesticide metabolites and a common assumption is that the subjects were exposed to the parent chemicals, rather than the metabolites.

The overall health benefits of high fruit and vegetable consumption are well documented [31, 35]. However, as recently indicated for effects on semen quality [103], these benefits might be compromised by the adverse effects of pesticide residues. When benefits are offset by a contaminant, a situation of inverse confounding occurs, which may be very difficult to adjust for [104]. The potential negative effects of dietary pesticide residues on consumer health should of course not be used as an argument for reducing fruit and vegetable consumption. Neither should nutrient contents be used to justify exposures to pesticides. Exposures related to the production of conventional crops (i.e. occupational or drift exposure from spraying) have been related to an increased risk of some diseases including Parkinson's disease [105-107], type 2 diabetes $[108,109]$ and certain types of cancers including non-Hodgkin lymphoma [110] and childhood leukaemia or lymphomas, e.g. after occupational exposure during pregnancy $[105,111]$ or residential use of pesticides during pregnancy $[105,112]$ or childhood [113]. To which extent these findings also relate to exposures from pesticide residues in food is unclear. However, foetal life and early childhood are especially vulnerable periods for exposure to neurotoxicants and endocrine disruptors. Even brief occupational exposure during the first weeks of pregnancy, before women know they are pregnant, have been related to adverse longlasting effects on their children's growth, brain functions and sexual development, in a Danish study on greenhouse worker's children [114-118].

In order to assess the potential health risk for consumers associated with exposure to dietary pesticides, reliance on epidemiological studies of sensitive health outcomes and their links to exposure measures is needed. Such studies are complicated both by difficult exposure assessment and the necessary long-term follow-up. The main focus so far has been on cognitive deficits in children in relation to their mother's exposure level to organophosphate insecticides during pregnancy. This line of research is highly appropriate given the known neurotoxicity of many pesticides in laboratory animal models [99] and the substantial vulnerability of the human brain during early development [119].

Most of the human studies have been carried out in the US and have focused on assessing brain functions in children in relation to prenatal organophosphate exposure. In a longitudinal birth cohort study among farmworkers in California (the CHAMACOS cohort), maternal urinary concentrations of organophosphate metabolites in pregnancy were associated with abnormal reflexes in neonates [120], adverse mental development at 2 years of age [121], attention problems at three and a half and 5 years [122], and poorer intellectual development at 7 years [123]. In accordance with this, a birth cohort study from New York reported impaired cognitive development at ages 12 and 24 months and 6 - 9 years related to maternal urine concentrations of organophosphates in pregnancy [124]. In another New York inner-city birth cohort, the concentration of the organophosphate chlorpyrifos in umbilical cord blood was associated with delayed psychomotor and mental development in children in the first 7 years of life [125], poorer working memory and full-scale IQ at 7 years of age [126], structural changes, including decreased cortical thickness, in the brain of the children at school age [127], and mild to moderate tremor in the arms at 11 years of age [128]. Based on these and similar studies, chlorpyrifos has recently been categorised as a human developmental neurotoxicant [129]. Recent reviews of neurodevelopmental effects of organophosphate insecticides in humans conclude that exposure during pregnancy - at levels commonly found in the general population - likely have negative effects on children's neurodevelopment [130-132]. In agreement with this conclusion, organophosphate pesticides considered to cause endocrine disruption contribute the largest annual health cost within the EU due to human exposures to such compounds, and these costs are primarily due to neurodevelopmental toxicity, as discussed below.

Since growth and functional development of the human brain continues during childhood, the postnatal period is also assumed to be vulnerable to neurotoxic exposures [119]. Accordingly, five-year-old children from the CHAMACOS cohort had higher risk scores for development of attention deficit hyperactive disorder (ADHD) if their urine concentration of organophosphate metabolites was elevated [122]. Based on cross-sectional data from the NHANES data base, the risk of developing ADHD increases by $55 \%$ for a ten-fold increase in the urinary concentration of organophosphate metabolites in children aged 8 to 15 years [133]. Also based on the NHANES data, children with detectable concentrations of pyrethroids in their urine are twice as likely to have ADHD compared with those below the detection limit [134]. In addition, associations between urinary concentrations of pyrethroid metabolites in children and parent-reported learning disabilities, ADHD or other behavioural problems in the children have recently been reported in studies from the US and Canada $[135,136]$.

So far only few prospective studies from the EU addressing associations between urinary levels of pesticides and neurodevelopment in children from the general population have been published. Three studies are based on the PELAGIE cohort in France and present 
results for organophosphates and pyrethroids respectively [81, 82, 137]. While no adverse effects on cognitive function in six-year-old children were related to maternal urine concentrations of organophosphates during pregnancy, the concentration of pyrethroid metabolites was associated with internalising difficulties in the children at 6 years of age. Also, the children's own urinary concentrations of pyrethroid metabolites were related to decrements in verbal and memory functions and externalising difficulties and abnormal social behaviour. While this sole European study did not corroborate US birth cohort studies results showing that exposure during pregnancy to organophosphate insecticides at levels found in the general population may harm brain development in the foetus, the exposure levels measured in the PELAGIE cohort were considerably lower for both organophosphates and pyrethroids than those measured in other European studies as well as in studies from the US and Canada. For example, the median urine concentration of organophosphate metabolites in pregnant women in the PELAGIE cohort was $2-6$ times lower than for pregnant women in other studies $[85,122,138]$ and the concentration of the common pyrethroid metabolite 3-PBA was only detectable in urine samples from $30 \%$ of the women compared to $80-90 \%$ in other studies $[88,139]$. Thus, to supplement the French study and the previously mentioned Danish study of greenhouse worker's children, additional studies that include more representative exposure levels for EU citizens are desirable.

Although exposure levels found in European countries are generally similar to or slightly higher than concentrations found in the US studies, the risk of adverse effects on neurodevelopment in European populations needs to be further characterised. The organophosphate insecticides contributing to the exposure might differ between the US and the EU, also in regard to oral and respiratory intakes. According to the European Food Safety Agency (EFSA), of all the organophosphate insecticides, chlorpyrifos most often exceeds the toxicological reference value (ARfD) [74]. A recent report utilised US data on adverse effects on children's IQ levels at school age to calculate the approximate costs of organophosphate exposure in the EU. The total number of IQ points lost due to these pesticides was estimated to be 13 million per year, representing a value of about $€ 125$ billion [140], i.e. about $1 \%$ of the EU's gross domestic product. Although there is some uncertainty associated with this calculation, it most likely represents an underestimation, as it focused only on one group of pesticides.

Unfortunately, epidemiological evidence linking pesticide exposure and human health effects is rarely regarded as sufficiently reliable to take into account in the risk assessment conducted by regulatory agencies.
For example, the conclusion from the epidemiological studies on chlorpyrifos is that an association of prenatal chlorpyrifos exposure and adverse neurodevelopmental outcomes is likely, but that other neurotoxic agents cannot be ruled out, and that animal studies show adverse effects only at 1000-fold higher exposures [141]. A recent decrease of the maximum residue limit for chlorpyrifos in several crops [142, 143] was based on animal studies only [144], but the limits for the sister compound, chlorpyrifos-methyl were unchanged. This case highlights a major limitation to current approaches to protecting the general population against a broad variety of pesticides.

\section{Production system and composition of plant foods}

Fertilisation in organic agriculture is based on organic fertilisers such as farmyard manure, compost and green fertilisers, while some inorganic mineral fertilisers are used as supplements. Nitrogen $(\mathrm{N})$ input is limited to $170 \mathrm{~kg} / \mathrm{ha}$ * year $[5,145]$. In conventional agriculture, fertilisation is dominated by mineral fertiliser, although farmyard manure is also common in some countries. There is no general limit on $\mathrm{N}$ input. Typically, crop yield is limited by plant $\mathrm{N}$ availability in organic but not in conventional systems [146] Phosphorus (P) input is on average similar or slightly lower in organic systems [147].

In the absence of particular nutrient deficiency, focusing on single nutrients may be of limited value for evaluating the impact of a food or diet on human health [49]; studies of actual health effects, as discussed above, are generally more informative than studies of single nutrients.

\section{Overall crop composition}

Metabolomics [148-152], proteomics [153, 154] and transcriptomics $[155,156]$ studies in controlled field trials provide evidence that the production system has an overall influence on crop development, although there is no direct relevance of these studies for human health. Furthermore, the generally lower crop yield in organic systems [146] as such indicates an effect of management strategy on plant development.

Several systematic reviews and meta-analyses [25, 157-159] with different scopes, inclusion criteria and statistical methods have summarised several hundred original studies reporting some aspect of plant chemical composition in relation to conventional and organic production, in search of overall trends across crops, varieties, soils, climates, production years etc. While the overall conclusions of these systematic reviews look contradictory at first sight, there is agreement between them in most of the detailed findings: 


\section{Nitrogen and phosphorus}

Existing systematic reviews have consistently found lower total nitrogen (7\% [157], 10\% [159]) and higher phosphorus (standardised mean difference (SMD) 0.82 [25], 8\% [157]) in organic compared to conventional crops. These findings lack direct relevance for human health. However, considering the differences in fertilisation strategies discussed above, and the fundamental importance of N, P [160-162], and the N:P ratio [163] for plant development, this may lend some plausibility to other observed effects of the production system on crop composition.

\section{Vitamins}

Systematic reviews generally agree that the concentration of macronutrients, vitamins, and minerals in crops is either not at all or only slightly affected by the production system. For example, ascorbic acid (vitamin C) has received most attention in this context. Meta-analyses report only small effect sizes of the organic production system on vitamin $\mathrm{C}$ content $[25,158,159]$.

\section{Polyphenols}

(Poly)phenolic compounds are not essential nutrients for humans but may play a role in preventing several non-communicable diseases, including cardiovascular disease, neurodegeneration and cancer [164]. The detailed mechanisms are complex and not fully understood [164]. Several environmental and agronomic practices affect the phenolic composition of the crop, including light, temperature, availability of plant nutrients and water management [165]. Under conditions of high nitrogen availability, many plant tissues show a decreased content of phenolic compounds, although there are examples of an opposite relationship [165].

Meta-analyses report modest effect sizes of the production system on total phenolics content, e.g. an increase of $14-26 \%[25,158,159]$. For some narrower groups of phenolic compounds, larger relative concentration differences (in percent) between organic and conventional crops have been reported [159]. However, such findings represent unweighted averages typically from small and few studies, and are therefore less reliable.

Collectively the published meta-analyses indicate a modestly higher content of phenolic compounds in organic food, but the evidence available does not constitute a sufficient basis for drawing conclusions on positive effects of organic compared to conventional plant products in regard to human health.

\section{Cadmium and other toxic metals}

Cadmium (Cd) is toxic to the kidneys, can demineralise bones and is carcinogenic [166]. Cd is present naturally in soils, and is also added to soils by $\mathrm{P}$ fertilisers and atmospheric deposition. Several factors, including soil structure and soil chemistry, humus content and $\mathrm{pH}$, affect the plant availability of $\mathrm{Cd}$ [167]. The application of $\mathrm{Cd}$-containing fertilisers increases $\mathrm{Cd}$ concentrations in the crops $[167,168]$. Low soil organic matter generally increases the availability of $\mathrm{Cd}$ for crops [169], and organically managed farms tend to have higher soil organic matter than conventionally managed farms [11].

The source of $\mathrm{Cd}$ in mineral fertilisers is the raw material phosphate rock. The European average $\mathrm{Cd}$ content in mineral fertilisers is reported as $68 \mathrm{mg} \mathrm{Cd} / \mathrm{kg} \mathrm{P} \mathrm{[170]} \mathrm{or}$ $83 \mathrm{mg} \mathrm{Cd} / \mathrm{kg} \mathrm{P}$ [171]. The content of $\mathrm{Cd}$ in farmyard manure is variable but apparently in many cases lower: Various types of animal manure in a German collection averaged between 14 and $37 \mathrm{mg} \mathrm{Cd} / \mathrm{kg} \mathrm{P} \mathrm{[172].}$

Smith-Spangler et al. [25] found no significant difference in the $\mathrm{Cd}$ content of organic and conventional crops (SMD $=-0.14,95 \%$ CI $-0.74-0.46)$ in their metaanalysis, while Barański et al. [159] report significantly $48 \%$ higher $\mathrm{Cd}$ concentration in conventional compared to organic crops $(\mathrm{SMD}=-1.45,95 \% \mathrm{CI}-2.52$ to -0.39 ) in another meta-analysis largely based on the same underlying original studies, albeit with different inclusion criteria. We contacted the authors of these metaanalyses in order to understand this discrepancy. An updated version of the Barański meta-analysis, in which some inconsistencies have been addressed and which has been provided by the original authors [173], shows a significant $30 \%(\mathrm{SMD}=-0.56,95 \% \mathrm{CI}-1.08$ to -0.04$)$ elevations of $\mathrm{Cd}$ contents in conventional compared to organic crops; in subgroup analysis, this difference is restricted to cereal crops. No updated meta-analysis was available for Smith-Spangler's analysis [25]; apparently, two large well-designed studies with tendencies towards a lower $\mathrm{Cd}$ content in organic crops were not considered $[174,175]$ although they appear to fulfil the inclusion criteria. Also, a correction for multiple testing has been imposed, which may be overly conservative, given the prior knowledge that mineral fertilisers constitute an important source of $\mathrm{Cd}$ to soils and crops. It is unclear how these points would affect the results of SmithSpangler's meta-analysis.

There are short-term and long-term effects of $\mathrm{Cd}$ influx from fertilisers on the Cd content of crops [167] but no long-term study comparing $\mathrm{Cd}$ content in organic and conventional crops is available. In absence of such direct evidence, two long-term experiments indicate a higher slope in $\mathrm{Cd}$ concentration over time for minerally fertilised compared to organically fertilised cereal crops [176, 177], after over 100 years of growing. 
A lower $\mathrm{Cd}$ content of organic crops is therefore plausible due to a lower $\mathrm{Cd}$ content in the fertilisers used in organic farming, and potentially due to higher soil organic matter in organic farmland. The general population's Cd exposure is close to, and in some cases above, the tolerable intake and therefore their exposure to $\mathrm{Cd}$ should be reduced. For non-smokers, food is the primary source of exposure, with cereals and vegetables being the most important contributors [168].

For other toxic metals including lead, mercury and arsenic, no differences in concentration in organic and conventional crops have been reported $[25,159]$. Uranium $(\mathrm{U})$ is also present as a contaminant of concern in mineral $P$ fertilisers [178], but less so in organic fertilisers [179], and consequently manure-based cropping systems have a lower $U$ load than mineral-fertilised systems at equal $P$ load [179]. Uranium appears to accumulate in mineralfertilised soils [180], and agricultural activity may increase the $U$ content of surface and groundwater [181, 182]. However, no evidence was found comparing uranium contents of organic and conventional products.

\section{Fungal toxins}

Regarding fungal toxins in crops, one meta-analysis has reported a lower contamination of organic compared to conventional cereal crops with deoxynivalenol (DON), produced by certain fusarium species [25]. Although not fully understood, fungicide applications may alter fungal communities on cereal leaves, potentially weakening disease-suppressive species [183, 184]. Also, crop rotations including non-cereal crops may contribute to lower infestation with fusarium [185], while $\mathrm{N}$ availability is positively associated with cereal DON content [186]. These factors give plausibility to the observed lower DON contamination in organic cereals. In the EU, the mean chronic exposure of toddlers, infants and children to DON is above the tolerable daily intake (TDI), with grains and grain-based products being the main contributors to total exposure. The TDI is based on decreased body weight gain observed in mice [187]. The production system does not have any observed effect on the concentration of ochratoxin A (OTA), another fungal toxin of importance in cereal production [25].

\section{Animal-based foods}

By regulation, herbivores in organic production receive at least $60 \%$ of their feed intake as roughage on a dry matter basis. Depending on the seasonal availability of pastures, roughage can be fresh, dried, or silage. Also omnivores in organic production receive roughage as part of their daily feed, and poultry has access to pasture [6]. Corresponding regulations are for the most part missing in conventional animal production. In consequence, feeding strategies in organic animal production include a higher fraction of roughage compared to conventional systems, e.g. for dairy cows $[188,189]$.

\section{Fatty acids}

Much of the focus of existing research on compositional differences of organic and conventional animal-based foods is on the fatty acid composition, with a major interest in omega-3 FAs due to their importance for human health. Some studies also address the content of minerals and vitamins.

The FA composition of the feed is a strong determinant of the fatty acid composition of the milk, egg or meat [190, 191]. Grass and red clover, typical roughage feeds, contain between $30 \%$ and $50 \%$ omega- 3 FA of total FA, while the concentrate feeds cereals, soy, corn, and palm kernel cake all contain below 10\% omega-3 FA of total FA [190]. Like humans, farm animals turn a small part of dietary alpha-linolenic acid into long-chain omega-3 fatty acids with the help of elongase and desaturase enzymes.

For cow's milk, a recent meta-analysis reports conclusively an approximately $50 \%$ higher content of total omega-3 fatty acids (as percent of total fatty acids) in organic compared to conventional milk [192], generally confirming earlier reviews $[25,189]$. Also, the content of ruminant FAs (a group of natural trans FAs produced in the cow's rumen) is higher in organic milk. The content of saturated fatty acids, mono-unsaturated fatty acids and omega-6 PUFA was similar in organic and conventional milk [192].

A considerable statistical heterogeneity in these findings is reported. Individual differences described above are based on results from between 11 and 19 included studies. The observed differences are plausible, because they are directly linked to differences in feeding regimens. It should also be noted that several other factors influence the fatty acid composition in milk [193]. Specifically, the season (indoor vs. outdoor) has an impact on the feeding regime [188] and therefore on the omega-3 content of milk. However, the content of omega-3 fatty acids is higher in organic milk during both the outdoor and indoor seasons [189].

For eggs, it is likewise well described that the FA composition of the feed [190] and consequently the access to pasture [194, 195] such as in organic systems, is a strong determinant of the fatty acid composition of the egg. However, only few studies have compared the FA composition in organic and conventional eggs [196] and a systematic review is not available. A higher omega-3 content of organic eggs is plausible but has not been documented.

A total of 67 original studies report compositional aspects of meat (mainly beef, chicken, lamb, and pork) from organic and conventional husbandry and were 
recently summarised in a meta-analysis [197]. Based on 23 and 21 studies respectively, the content of total PUFA and omega-3 PUFA was found to be significantly higher (23 and 47\%, respectively) in organic compared to conventional meats. Weighted by average consumption in Europe, choosing organic instead of conventional meat, while maintaining a constant consumption, increased the intake of PUFA and omega-3 FA from meat by 17 and $22 \%$, respectively [198]. These findings are plausible, especially in the case of omega-3 PUFA, considering the known differences in feeding regimens in organic and conventional production. However, few studies were available for each analysis, leaving many analyses with high uncertainty and poor statistical power. Furthermore, fatty acid metabolism differs between ruminants and monogastric animals [190]. Also, the actual differences in feeding regimens between conventionally and organically raised animals may differ by species, and by country. The variation between studies and between species was large, and the overall reliability of these results is therefore lower compared to milk above. This meta-analysis therefore indicates a plausible increase in omega-3 contents in organic meats, but more well-designed studies are needed to confirm this effect [197].

Dairy products account for $4-5 \%$ of the total PUFA intake in most European populations, while meat and meat products contribute another 7-23\% [199]. The contribution of milk fat to omega-3 PUFA intake (approximated as intake of $\alpha$-linolenic acid) has been estimated at $5-16 \%[200,201]$, while meat contributes with $12-17 \%$ [201, 202]. The effect of exchanging organic for conventional dairy products on omega-3 PUFA intake while maintaining a constant consumption has not been examined rigorously. From the intake and composition data presented here, it can be estimated that choosing organic products would increase the average dietary omega-3 PUFA intake by $2.5-8 \%$ (dairy) and by a less certain $2.5-4 \%$ (meat). A recent preliminary estimate based on FAO food supply data resulted in similar numbers [198]. For certain population groups and fatty acids, these numbers could be higher, and an increased omega-3 PUFA consumption is generally desirable, as some subpopulations have a lower-thanrecommended intake of omega-3 PUFA [203]. However, overall, the effect of the animal production system on omega-3 PUFA intake is minor, and no specific health benefits can be derived. Furthermore, other dietary omega-3 PUFA sources, specifically certain plant oils and fish, are available that carry additional benefits [204-206]. The existence of specific health benefits of ruminant trans fatty acids (as opposed to industrial trans fatty acids) is indicated by some studies [207] but not strongly supported [208]. Taking into account the actually consumed amounts of ruminant trans fatty acids, this is likely lacking public health relevance [208].

\section{Trace elements and vitamins}

A recent meta-analysis points to a significantly higher content of iodine $(74 \%)$ and selenium $(21 \%)$ in conventional milk and of iron (20\%) and tocopherol (13\%) in organic milk based on six, four, eight and nine studies respectively [192]. Iodine deficiency during pregnancy and infancy leads to impairment of brain development in the offspring, while excess iodine intake is associated with similar effects, and the window of optimal iodine intake is relatively narrow [209]. Overall, iodine intake in Europe is low and mild deficiency is prevalent [210]. The preferred way of correcting deficiency is salt iodisation [210, 211], because salt is consumed almost universally and with little seasonal variation [212].

Feed iodine supplementation is not linked by regulation to the production system in the EU, as iodine is listed as approved feed additive, and the maximum amount of supplementation is the same for all milk production. Optimum dairy cow supplementation should be seen in relation to other national strategies for human iodine intake. This should also take into account human subpopulations with low or no intake of dairy products.

For tocopherol, selenium and iron, a higher content is generally desirable, and in the case of selenium milk is an important source. However, the concentration differences between organic and conventional milk are modest and based on a few studies only.

\section{Antibiotic resistant bacteria}

Overly prevalent prophylactic use of antibiotics in animal production is an important factor contributing to increasing human health problems due to resistant bacteria. Antibiotic use is strongly restricted in organic husbandry, which instead aims to provide good animal welfare and enough space in order to promote good animal health.

Antibiotics constitute an integral part of intensive animal production today, and farm animals may act as important reservoirs of resistant genes in bacteria [213, 214]. It is reported that a substantial proportion $(50-80 \%)$ of antibiotics are used for livestock production worldwide [215]. On a "per kg biomass" basis, in 2014, the amount of antimicrobial drugs consumed by farm animals was slightly higher than the antimicrobial drugs used for humans in the 28 EU/EEA countries surveyed, with substantial differences between countries regarding volumes and types of substances [216].

In recent decades, there have been increasing concerns that the use of antibiotics in livestock would contribute to impairing the efficiency of antibiotic treatment in human medical care [217]. Despite the lack of detailed information on transmission routes for the vast flora of 
antibiotic-resistant bacteria and resistance genes, there is a global need for action to reduce the emerging challenges associated with the reduced efficiency of antibiotics and its consequences for public health, as well as for the environment more generally [218, 219].

The use of antibiotics may increase the economic outcome of animal production [220, 221], but the spreading of multi-resistant genes is not just a problem for the animal production sector alone. Negative effects are affecting parts of society not directly associated with livestock production. This means that the costs of side effects are borne by society in general and not primarily by the agricultural sector. However, the generalisation cannot be made that all antibiotic treatment in farm animals represents a hazard to public health [222, 223].

The use of antibiotics in intensive livestock production is closely linked to the housing and rearing conditions of farm animals. Specific conditions for conventional livestock farming in different countries, as well as farmers' attitudes, may differ between countries, e.g. conventional pig production at above EU animal welfare standards and farmers' attitudes in Sweden [224, 225]. Conventional production is typically aiming for high production levels with restricted input resources such as space, feed etc., and these conditions may cause stress in the individual animal as it is unable to cope with the situation, e.g. in pig production [226, 227]. This means that higher stocking density, restricted space and barren environment are factors increasing the risk of the development of diseases, and therefore it is more likely that animals under these conditions need antibiotic treatments.

Organic production aims for less intensive animal production, which generally means that the animals have access to a more spacious and enriched environment, access to an outdoor range and restricted group sizes, and other preconditions [70]. This would ultimately decrease the need for preventive medication of the animals as they can perform more natural behaviours and have more opportunity to maintain a good health. However, in practice, the health status of organic livestock is complex and disease prevention needs to be adapted to the individual farm [228]. A report on the consequences of organic production in Denmark demonstrates that meeting the requirements of organic production has several positive consequences in relation to animal welfare and health [70].

According to EU regulations, routine prophylactic medication of animals in organic production is not allowed. However, diseases should be treated immediately to avoid suffering, and the therapeutic use of antibiotics is allowed, but with longer withdrawal periods than in conventional production [5]. Furthermore, products from animals treated more than three times during 12 months, or, if their productive lifecycle is less than
1 year, more than once, cannot be sold as organic [6]. This means that therapeutically the same antibiotics used in conventional farming may be used in organic farming, but under different conditions. For example, antibiotics mainly used for sub-therapeutic treatment as prophylaxis are never considered in organic production.

While the organic regulations aim for a low use of antibiotics in livestock production, the actual use of antibiotic drugs in European organic compared to conventional animal husbandry is not comprehensively documented. Scattered studies indicate that the antibiotic use generally is substantially higher in conventional compared to organic systems, especially for pigs (approximately 5 - 15-fold higher) [229, 230]. In studies from Denmark [231] and the Netherlands [232], the antibiotic use in dairy cows was 50\% and 300\% higher in conventional compared to organic systems, although a Swedish study found no differences in disease treatment strategies between organic and conventional dairy farms, e.g. for mastitis [233]. While only sparingly documented (e.g. [234, 235]), there is only little use of antibiotics in EU organic broiler production. This is a consequence of regulations prohibiting prophylactic use and prescribing long withdrawal periods before slaughter $[6,236]$, in conjunction with the fact that it is not feasible to treat single animals in broiler flocks. In conventional broiler production, antibiotic use is common (e.g. [237-239]).

Recently, gene sequencing has revealed that the routes of transmission of resistance genes between human and farm animal reservoirs seem to be complex [213, 222, 240]. Nevertheless, a recent EFSA report found that "in both humans and animals, positive associations between consumption of antimicrobials and the corresponding resistance in bacteria were observed for most of the combinations investigated" [241], which has subsequently been strengthened [216]. In addition to direct transmission between animals and humans via contact or via food, resistant strains and resistance genes may also spread into the environment [242].

Previously, it has been postulated that a reduced need and use of antibiotics in organic livestock production will diminish the risk of development of antibiotic resistance [243], and this has also been demonstrated with regard to resistant $E$. coli in organic pigs compared to conventional pigs [244]. It has also been shown that the withdrawal of prophylactic use of antibiotics when poultry farms are converted from conventional to organic production standards leads to a decrease in the prevalence of antibiotic-resistant Salmonella [245].

Resistant bacteria may be transferred within the production chain from farm to fork [246]. It has been found that organic livestock products are less likely to harbour resistant bacteria in pork and chicken meat [25]. 
In pig production, particular attention has been paid to methicillin-resistant Staphylococcus aureus (MRSA), and in Dutch and German studies, for example, MRSA has been isolated in 30 and $55 \%$ respectively of all pigs tested [247, 248]. Furthermore, it has been found that healthy French pig farmers are more likely to carry MRSA than control persons [249] and that they carry similar strains of MRSA to those found on their pig farms [250]. However, the prevalence of MRSA in pig production may differ between conventional and organic farms, and in a meta-study in 400 German fattening pig herds, the odds ratio (OR) for MRSA prevalence was $0.15(95 \%$ CI $0.04,0.55)$ in organic $(n=23)$ compared to conventional $(n=373)$ pig farms [248]. Multivariate adjustment for potential risk factors rendered this association non-significant, suggesting that it was carried by other factors, including factors that are regulated in or associated with organic production, such as non-slatted floors, no use of antibiotics, and farrow-to-finish herd types. Furthermore, even if there are considerable differences in antibiotic use between countries, it has been found that antibiotic resistance is less common in organic pigs compared to conventional pigs in France, Italy, Denmark, and Sweden [251, 252].

Although it is rare for conventional farms to adopt knowledge about management and housing from organic production except when converting farms in line with organic standards, there may be options to improve animal health and welfare by knowledge transfer to conventional farms in order to reduce the use of antibiotics [253].

Within organic production, labelling requires full traceability in all steps in order to guarantee the origin of the organic products being marketed [5]. Application of the general principle of organic regulations about transparency throughout the food chain can be used to mitigate emerging problems of transmission of antimicrobial resistance. However, transition to organic production for the whole livestock sector would, on its own, be only part of a solution to the antibiotics resistance issue, because factors outside animal production, such as their use in humans, will be unaffected.

\section{Discussion}

An assessment of the human health effects associated with diets based on organic food production must rely on two sets of evidence. The first set of evidence is the epidemiological studies comparing population groups with dietary habits that differ substantially in regard to choices of organic v. conventional products. These studies are to some extent complemented by experimental studies using animal models and in vitro models. The second set of data relies on indirect evidence such as chemical analyses of food products and their contents of nutrients and contaminants or antibiotic use and resistance patterns, in onsequence of agricultural production methods. Both sets of results are associated with certain strengths and weaknesses.

The few human studies that have directly investigated the effects of organic food on human health have so far yielded some observations, including indications of a lower risk of childhood allergies, adult overweight/obesity $[18,46]$ and non-Hodgkin lymphoma (but not for total cancer) [37] in consumers of organic food. Owing to the scarcity or lack of prospective studies and the lack of mechanistic evidence, it is presently not possible to determine whether organic food plays a causal role in these observations. However, it has also been observed that consumers who prefer organic food have healthier dietary patterns overall, including a higher consumption of fruit, vegetables, whole grains, and legumes and a lower consumption of meat $[18,29,37]$. This leads to some methodological difficulties in separating the potential effect of organic food preference from the potential effect of other associated lifestyle factors, due to residual confounding or unmeasured confounders. These dietary patterns have in other contexts been associated with a decreased risk of several chronic diseases, including diabetes and cardiovascular disease [30-36]. It is therefore expected that consumers who regularly eat organic food have a decreased risk of these diseases compared to people consuming conventionallyproduced food, as a consequence of dietary patterns. These dietary patterns appear also to be more environmentally sustainable than average diets [254].

Food analyses tend to support the notion that organic foods may have some health benefits. Consumers of organic food have a comparatively low dietary exposure to pesticides. Although chemical pesticides undergo a comprehensive risk assessment before market release in the EU, there are important gaps in this risk assessment. In some cases, specifically for cognitive development during childhood as an effect of organophosphate insecticide exposure during pregnancy, epidemiological studies provide evidence of adverse effects [140, 255]. Organic agriculture allows for lower pesticide residues in food and may be instrumental in conventional agriculture's transition towards integrated pest management by providing a large-scale laboratory for nonchemical plant protection.

This review emphasizes that pesticide exposure from conventional food production constitutes a main health concern. A key issue that has only recently been explored in biomedical research is that early-life exposure is of major concern, especially prenatal exposure that may harm brain development. Most insecticides are designed to be toxic to the insect nervous system, but many higher species depend on similar neurochemical 
processes and may therefore all be vulnerable to these substances [129]. Besides insecticides, experimental studies suggest a potential for adverse effects on the nervous system for many herbicides and fungicides as well [99]. However, no systematic testing is available since testing for neurotoxicity - especially developmental neurotoxicity - has not consistently been required as part of the registration process, and allowable exposures may therefore not protect against such effects. At least 100 different pesticides are known to cause adverse neurological effects in adults [129], and all of these substances must therefore be suspected of being capable of damaging also developing brains. The need for prevention of these adverse outcomes is illustrated by the recent cost calculations [140] and the additional risk that pesticide exposures may lead to important diseases, such as Parkinson's disease, diabetes and certain types of cancer.

The outcomes in children and adults and the dosedependences are still incompletely documented, but an additional limitation is the lack of exposure assessments in different populations and also their association with dietary habits. The costs from pesticide use in regard to human health and associated costs to society are likely to be greatly underestimated due to hidden and external costs, as recently reviewed [256]. Also, gaps in the regulatory approval process of pesticides may lead to important effects being disregarded and remaining undetected.

In regard to nutrients, organic dairy products, and probably also meat, have an approximately 50\% higher content of omega-3 fatty acids compared to conventional products. However, as these products only are a minor source of omega- 3 fatty acids in the average diet, the nutritional significance of this effect is probably low (although this has not been proven). The nutritional content of crops is largely unaffected by the production system, according to current knowledge. Vitamins and minerals are found in similar concentrations in crops from both systems. One exception is the increased content of phenolic compounds found in organic crops, although this is still subject to uncertainty despite a large number of studies that have addressed this issue. Accordingly, although in general being favourable for organic products, the established nutritional differences between organic and conventional foods are small, and strong conclusions for human health cannot currently be drawn from these differences. There are indications that organic crops contain less cadmium compared to conventional crops. This is plausible, primarily because mineral fertiliser is an important source of cadmium in soils. However, notably, long-term farm pairing studies or field trials that are required for definitely establishing or disproving this relationship are lacking. Owing to the high relevance of cadmium in food for human health, this lack of research constitutes an important knowledge gap.
With respect to the development of antibiotic resistance in bacteria, organic animal production may offer a way of restricting the risks posed by intensive production, and even decreasing the prevalence of antibiotic resistance. Organic farm animals are less likely to develop certain diseases related to intensive production compared to animals on conventional farms. As a consequence, less antibiotics for treating clinical diseases are required under organic management, where their prophylactic use also is strongly restricted. This decreases the risk for development of antibiotic resistance in bacteria. Furthermore, the transparency in organic production may be useful for acquiring knowledge and methods to combat the rising issues around transmission of antimicrobial resistance within food production.

It appears essential that use of antibiotics in animal production decreases strongly or completely ceases in order to decrease the risk of entering a post-antibiotic era. The development and upscaling of rearing systems free or low in antibiotic use, such as organic broiler production, may be an important contribution of organic agriculture to a future sustainable food system.

Most of the studies considered in this review have investigated the effects of agricultural production on product composition or health. Far less attention has been paid to the potential effects of food processing. Processing may affect the composition of foods and the bioavailability of food constituents. It is regulated [5] and recognised [257] that food additives are restricted for organic products compared to conventional products. It is also recognised that the degree of food processing may be of relevance to human health [258, 259]. In organic food processing, the processing should be done "with care, preferably with the use of biological, mechanical and physical methods" [5] but there are no specific restrictions or guidelines. With the exception of chemical additives, it is unknown whether certain food processing methods (e.g. fermentation of vegetables, pasteurisation of vegetables) are more prevalent in organic or conventional products or consumption patterns, or whether such differences are of relevance to human health.

The scopes of two recent reports, from Norway [260] and Denmark [70], in part overlap with the present work. Broadly, the reviewed results and conclusions presented in those reports are in line with this article. For several topics, important new evidence has been published in recent years. Consequently, in some cases stronger conclusions can be drawn today. Furthermore, the present review includes epidemiological studies of pesticide effects in the evidence base reviewed.

Over all, the evidence available suggested some clear and some potential advantages associated with organic 
foods. The advantages in general do not necessarily require organic food production as strictly defined in current legislation. Certain production methods, such as changes in the use of pesticides and antibiotics, can be implemented in conventional production, e.g. supporting a development towards a sustainable use of pesticides [261]. Thereby, practices and developments in organic agriculture can have substantial public health benefits also outside the organic sector.

Diet choices and the associated food production methods also have important impacts on environmental sustainability [254]. Consumption patterns of consumers preferring organic food $[16,18,19,37,47]$ seem to align well with sustainable diets [2]. These consumption patterns also show some similarities with the Mediterranean Diet [262-265] and with the New Nordic Diet [266-269], with lower dietary footprints in regard to land use, energy and water consumption, and greenhouse gas emissions compared to concurrent average diets. Further evaluation is needed to assess the extent to which organic food systems can serve as example of a sustainable food systems [270].

For the development of healthy and environmentallysustainable food systems in the future, production and consumption need to be considered in an integrated manner [2, 271]. While an evaluation of overall impacts of different food systems on environmental sustainability would be highly desirable [270], the present review has attempted to assess the human health issues in regard to organic production methods and consumer preferences for organic food, both important aspects of sustainability.

\section{Conclusions}

Suggestive evidence indicates that organic food consumption may reduce the risk of allergic disease and of overweight and obesity, but residual confounding is likely, as consumers of organic food tend to have healthier lifestyles overall. Animal experiments suggest that growth and development is affected by the feed type when comparing identically composed feed from organic or conventional production. In organic agriculture, the use of pesticides is restricted, and residues in conventional fruits and vegetables constitute the main source of human exposures. Epidemiological studies have reported adverse effects of certain pesticides on children's cognitive development at current levels of exposure, but these data have so far not been applied in the formal risk assessments of individual pesticides. The nutrient composition differs only minimally between organic and conventional crops, with modestly higher contents of phenolic compounds in organic fruit and vegetables. There is likely also a lower cadmium content in organic cereal crops. Organic dairy products, and perhaps also meats, have a higher content of omega- 3 fatty acids compared to conventional products, although this difference is of likely of marginal nutritional significance. Of greater concern is the prevalent use of antibiotics in conventional animal production as a key driver of antibiotic resistance in society; antibiotic use is less intensive in organic production. Thus, organic food production has several documented and potential benefits for human health, and wider application of these production methods also in conventional agriculture, e.g., in integrated pest management, would therefore most likely benefit human health.

\section{Abbreviations \\ 3-PBA: 3-phenoxybenzoic acid; ADHD: Attention deficit hyperactivity disorder; ADI: Acceptable daily intake; AOEL: Acceptable operator exposure level; ARfD: Acute reference dose; BMl: Body mass index; BSE: Bovine spongiform encephalopathy; Cd: Cadmium; CHAMACOS: Center for the health assessment of mothers and children of Salinas; Cl: Confidence interval; DAP: Dialkyl phosphate; DDT: Dichlorodiphenyltrichloroethane; \\ DON: Deoxynivalenol; E. coli: Escherichia coli; EEA: European Economic Area; EFSA: European Food Safety Authority; EU: European Union; FA: Fatty acid; FAO: Food and Agriculture Organization of the United Nations; ha: Hectare; HI: Hazard index; IgG: Immunoglobulin G; IPM: Integrated pest management; IQ: Intelligence quotient; MRL: Maximum residue level; MRSA: Methicillin- resistant Staphylococcus aureus; N: Nitrogen; NHANES: National health and nutrition examination survey; OR: Odds ratio; OTA: Ochratoxin A; \\ P: Phosphorus; PBT: Persistent, bioaccumulative, toxic; PELAGIE: Perturbateurs endocriniens: étude longitudinale sur les anomalies de la grossesse, \\ l'infertilité et l'enfance (endocrine disruptors: longitudinal study on disorders of pregnancy, infertility and children); PUFA: Polyunsaturated fatty acid; RR: Relative risk; SMD: Standardized mean difference; TDI: Tolerable daily intake; U: Uranium; UK: United Kingdom; US: United States}

\section{Acknowledgements}

The present review was initiated after a workshop entitled "The impact of organic food on human health" organized by the European Parliament in Brussels, Belgium on 18 November 2015, in which several of the authors participated, and which resulted in a formal report to the European Parliament [199]. The present review is an updated and abbreviated version aimed for the scientific community. The authors would like to thank the following colleagues for critically reading and reviewing sections of the review: Julia Baudry, Nils Fall, Birgitta Johansson, Håkan Jönsson, Denis Lairon, Kristian Holst Laursen, Jessica Perry, Paula Persson, Helga Willer and Maria Wivstad. The authors would also like to thank Marcin Barański and Gavin Stewart for providing additional meta-analyses of cadmium contents in organic and conventional crops. The STOA staff is acknowledged for organising the seminar in Brussels.

\section{Funding}

The Science and Technology Options Assessment Panel of the European Parliament provided funding for writing this paper, travel support to the authors and coverage of incidental expenses.

\section{Availability of data and material \\ Not relevant.}

\section{Authors' contributions}

AM, PG and GQ drafted the introduction. EKG drafted the human studies section. JK drafted the food consumption pattern aspects in the human studies section and in the discussion. AM and ER drafted the in vitro and animal studies section. HRA and PG drafted the pesticides section. AM and ER drafted the plant foods section. AM drafted the animal foods section. SG drafted the antibiotic resistance section. AM and PG drafted the discussion and conclusions. All authors commented on the entire draft and approved the final version.

Ethics approval and consent to participate Not applicable. 


\section{Consent for publication}

All authors approved the manuscript for publication.

\section{Competing interests}

The authors have no conflict of interest to report. AM has participated as an expert witness in a court case in Sweden related to pesticide exposure from organic and conventional foods (Patent and Market Courts, case no. PMT11299-16), but did not benefit financially from this effort. PG is an editor of this journal but recused himself from participating in the handling of this manuscript.

\section{Publisher's Note}

Springer Nature remains neutral with regard to jurisdictional claims in published maps and institutional affiliations.

\section{Author details}

'Karolinska Institutet, Department of Clinical Science and Education Södersjukhuset, 11883 Stockholm, Sweden. ${ }^{2}$ Swedish University of Agricultural Sciences (SLU), Centre for Organic Food and Farming (EPOK), Ultuna, Sweden. ${ }^{3}$ University of Southern Denmark, Department of Public Health, Odense, Denmark. ${ }^{4}$ Swedish University of Agricultural Sciences (SLU), Department of Animal Environment and Health, Skara, Sweden. ${ }^{5}$ University of Copenhagen, Department of Nutrition, Exercise and Sports, Frederiksberg, Denmark. ${ }^{6}$ Research Unit on Nutritional Epidemiology (U1153 Inserm, U1125 INRA, CNAM, Université Paris 13), Centre of Research in Epidemiology and Statistics Sorbonne Paris Cité, Bobigny, France. ${ }^{7}$ Warsaw University of Life Sciences, Department of Functional \& Organic Food \& Commodities, Warsaw, Poland. ${ }^{8}$ Scientific Foresight Unit (Science and Technology Options Assessment [STOA]), Directorate-General for Parliamentary Research Services (EPRS), European Parliament, Brussels, Belgium. ${ }^{9}$ Harvard T.H. Chan School of Public Health, Department of Environmental Health, Boston, USA.

Received: 22 May 2017 Accepted: 2 October 2017

Published online: 25 October 2017

\section{References}

1. WHO: Health indicators of sustainable agriculture, food and nutrition security in the context of the Rio+20 UN Conference on Sustainable Development. www.who.int/hia/green_economy/indicators_food.pdf. 2012(accessed 2017-09-11).

2. Burlingame B, Dernini S. Food and Agriculture Organization of the United Nations (FAO): Sustainable diets and biodiversity. Directions and solutions for policy, research and action. In. Edited by Burlingame B, Dernini S; 2012

3. Sustainable Food Systems Programme; 2016. [http://www.unep.org/10yfp/ programmes/sustainable-food-systems-programme].

4. The World of Organic Agriculture. Statistics and emerging trends. Frick and Bonn: FiBL and IFOAM - organics international; 2017.

5. Council of the European Union: Council Regulation No 834/2007 of 28 June 2007 on organic production and labelling of organic products and repealing Regulation (EEC) No 2092/91. In: Off J Eur Union 2007.

6. European Commission: Commission Regulation (EC) No 889/2008 of 5 September 2008 laying down detailed rules for the implementation of Council Regulation (EC) No 834/2007 on organic production and labelling of organic products with regard to organic production, labelling and control. In: Off J Eur Union 2008.

7. Willer H, Schaack D, Lernoud J: Organic Farming and Market Development in Europe and the European Union. In: The World of Organic Agriculture Statistics and Emerging Trends 2017. Edited by Willer H, Lernoud J. Frick and Bonn: FiBL and IFOAM; 2017

8. Eurostat. http://ec.europa.eu/eurostat. Accessed 19 Sept 2017

9. FAOSTAT. http://www.fao.org/faostat. Accessed 19 Sept 2017.

10. Facts and figures on organic agriculture in the European Union. [http://ec.europa.eu/agriculture/rica/pdf/Organic_2016_web_new.pdf]. Accessed 19 Sept 2017

11. Reganold JP, Wachter JM. Organic agriculture in the twenty-first century. Nat Plants. 2016:2:15221.

12. Seufert V, Ramankutty N. Many shades of gray-the context-dependent performance of organic agriculture. Sci Adv. 2017:3(3):e1602638.

13. Tscharntke T, Clough Y, Wanger TC, Jackson L, Motzke I, Perfecto I, Vandermeer J, Whitbread A. Global food security, biodiversity conservation and the future of agricultural intensification. Biol Conserv. 2012;151(1):53-9.
14. Wheeler T, von Braun J. Climate change impacts on global food security Science. 2013:341(6145):508-13.

15. Oates L, Cohen M, Braun L. Characteristics and consumption patterns of Australian organic consumers. J Sci Food Agric. 2012;92(14):2782-7.

16. Baudry J, Mejean C, Alles B, Peneau S, Touvier M, Hercberg S, Lairon D, Galan P, Kesse-Guyot E. Contribution of organic food to the diet in a large sample of French adults (the NutriNet-Sante cohort study). Nutrients. 2015 7(10):8615-32

17. Baudry J, Touvier M, Alles B, Peneau S, Mejean C, Galan P, Hercberg S, Lairon D, Kesse-Guyot E. Typology of eaters based on conventional and organic food consumption: results from the NutriNet-Sante cohort study. Br J Nutr. 2016;116(4):700-9.

18. Kesse-Guyot E, Peneau S, Mejean C, Szabo de Edelenyi F, Galan P, Hercberg S, Lairon D. Profiles of organic food consumers in a large sample of French adults: results from the Nutrinet-Sante cohort study. PLoS One. 2013:8(10): e76998.

19. Eisinger-Watzl M, Wittig F, Heuer T, Hoffmann I. Customers purchasing organic food - do they live healthier? Results of the German National Nutrition Survey II. Eur J Nutr Food Saf. 2015;5(1):59-71.

20. Hughner RS, McDonagh P, Prothero A, Shultz CJ, Stanton J. Who are organic food consumers? A compilation and review of why people purchase organic food. J Consum Behav. 2007;6(2-3):94-110.

21. van de Vijver LP, van Vliet ME. Health effects of an organic diet-consumer experiences in the Netherlands. J Sci Food Agric. 2012;92(14):2923-7.

22. Brown E, Dury S, Holdsworth M. Motivations of consumers that use local, organic fruit and vegetable box schemes in Central England and southern France. Appetite. 2009;53(2):183-8.

23. Arvola A, Vassallo M, Dean M, Lampila P, Saba A, Lahteenmaki L, Shepherd R. Predicting intentions to purchase organic food: the role of affective and moral attitudes in the theory of planned behaviour. Appetite. 2008;50(2-3): 443-54.

24. Dangour AD, Lock K, Hayter A, Aikenhead A, Allen E, Uauy R. Nutritionrelated health effects of organic foods: a systematic review. Am J Clin Nutr. 2010:92(1):203-10.

25. Smith-Spangler C, Brandeau ML, Hunter GE, Bavinger JC, Pearson M, Eschbach PJ, Sundaram V, Liu H, Schirmer P, Stave C, et al. Are organic foods safer or healthier than conventional alternatives?: a systematic review. Ann Intern Med. 2012;157(5):348-66.

26. Forman J, Silverstein J. Organic foods: health and environmental advantages and disadvantages. Pediatrics. 2012;130(5):e1406-15.

27. Mark AB, Poulsen MW, Andersen S, Andersen JM, Bak MJ, Ritz C, Holst JJ, Nielsen J, de Courten B, Dragsted LO, et al. Consumption of a diet low in advanced glycation end products for 4 weeks improves insulin sensitivity in overweight women. Diabetes Care. 2014;37(1):88-95.

28. Soltoft M, Bysted A, Madsen KH, Mark AB, Bugel SG, Nielsen J, Knuthsen P. Effects of organic and conventional growth systems on the content of carotenoids in carrot roots, and on intake and plasma status of carotenoids in humans. J Sci Food Agric. 2011;91(4):767-75.

29. Torjusen H, Brantsaeter AL, Haugen M, Alexander J, Bakketeig LS, Lieblein G, Stigum H, Naes T, Swartz J, Holmboe-Ottesen G, et al. Reduced risk of preeclampsia with organic vegetable consumption: results from the prospective Norwegian mother and child cohort study. BMJ Open. 2014; 4(9):e006143.

30. Abete I, Romaguera D, Vieira AR, Lopez de Munain A, Norat T. Association between total, processed, red and white meat consumption and all-cause, CVD and IHD mortality: a meta-analysis of cohort studies. Br J Nutr. 2014; 112(5):762-75.

31. Boeing $H$, Bechthold A, Bub A, Ellinger $S$, Haller D, Kroke A, Leschik-Bonnet E, Muller MJ, Oberritter $H$, Schulze $M$, et al. Critical review: vegetables and fruit in the prevention of chronic diseases. Eur J Nutr. 2012;51(6):637-63.

32. Larsson SC, Orsini N. Red meat and processed meat consumption and allcause mortality: a meta-analysis. Am J Epidemiol. 2014;179(3):282-9.

33. Li F, Hou LN, Chen W, Chen PL, Lei CY, Wei Q, Tan WL, Zheng SB. Associations of dietary patterns with the risk of all-cause, CVD and stroke mortality: a meta-analysis of prospective cohort studies. Br J Nutr. 2015; 113(1):16-24.

34. Schwingshackl L, Hoffmann G. Diet quality as assessed by the healthy eating index, the alternate healthy eating index, the dietary approaches to stop hypertension score, and health outcomes: a systematic review and meta-analysis of cohort studies. J Acad Nutr Diet. 2015;115(5):780-800.e785 
35. Wang X, Ouyang Y, Liu J, Zhu M, Zhao G, Bao W, Hu FB. Fruit and vegetable consumption and mortality from all causes, cardiovascular disease, and cancer: systematic review and dose-response meta-analysis of prospective cohort studies. BMJ. 2014;349:94490.

36. Zong G, Gao A, Hu FB, Sun Q. Whole grain intake and mortality from all causes, cardiovascular disease, and cancer: a meta-analysis of prospective cohort studies. Circulation. 2016;133(24):2370-80.

37. Bradbury KE, Balkwill A, Spencer EA, Roddam AW, Reeves GK, Green J, Key TJ, Beral V, Pirie K. The million women study C: organic food consumption and the incidence of cancer in a large prospective study of women in the United Kingdom. Br J Cancer. 2014;110(9):2321-6.

38. Alfven T, Braun-Fahrlander C, Brunekreef B, von Mutius E, Riedler J, Scheynius A, van Hage M, Wickman M, Benz MR, Budde J, et al. Allergic diseases and atopic sensitization in children related to farming and anthroposophic lifestyle-the PARSIFAL study. Allergy. 2006;61(4):414-21.

39. Kummeling I, Thijs C, Huber M, van de Vijver LP, Snijders BE, Penders J Stelma F, van Ree R, van den Brandt PA, Dagnelie PC. Consumption of organic foods and risk of atopic disease during the first 2 years of life in the Netherlands. Br J Nutr. 2008;99(3):598-605.

40. Rist L, Mueller A, Barthel C, Snijders B, Jansen M, Simoes-Wust AP, Huber M, Kummeling I, von Mandach U, Steinhart $\mathrm{H}$, et al. Influence of organic diet on the amount of conjugated linoleic acids in breast milk of lactating women in the Netherlands. Br J Nutr. 2007;97(4):735-43.

41. Stenius F, Swartz J, Lilja G, Borres M, Bottai M, Pershagen G, Scheynius A, Alm J. Lifestyle factors and sensitization in children - the ALADDIN birth cohort. Allergy. 2011;66(10):1330-8.

42. Fagerstedt $\mathrm{S}$, Hesla HM, Ekhager $\mathrm{E}$, Rosenlund $\mathrm{H}$, Mie A, Benson L, Scheynius A, Alm J. Anthroposophic lifestyle is associated with a lower incidence of food allergen sensitization in early childhood. J Allergy Clin Immunol. 2016; 137(4):1253-1256.e1251.

43. Alm JS, Swartz J, Lilja G, Scheynius A, Pershagen G. Atopy in children of families with an anthroposophic lifestyle. Lancet. 1999;353(9163): $1485-8$.

44. Floistrup H, Swartz J, Bergstrom A, Alm JS, Scheynius A, van Hage M, Waser M, Braun-Fahrlander C, Schram-Bijkerk D, Huber M, et al. Allergic disease and sensitization in Steiner school children. J Allergy Clin Immunol. 2006; 117(1):59-66.

45. Thijs C, Muller A, Rist L, Kummeling I, Snijders BE, Huber M, van Ree R, Simoes-Wust AP, Dagnelie PC, van den Brandt PA. Fatty acids in breast milk and development of atopic eczema and allergic sensitisation in infancy. Allergy. 2011;66(1):58-67.

46. Kesse-Guyot E, Baudry J, Assmann KE, Galan P, Hercberg S, Lairon D. Prospective association between consumption frequency of organic food and body weight change, risk of overweight or obesity: results from the NutriNet-Santé study. Br J Nutr. 2017;117(2):325-34.

47. Baudry J, Mejean C, Peneau S, Galan P, Hercberg S, Lairon D, Kesse-Guyot E. Health and dietary traits of organic food consumers: results from the NutriNet-Sante study. Br J Nutr. 2015;114(12):2064-73.

48. Alfano CM, Day JM, Katz ML, Herndon JE 2nd, Bittoni MA, Oliveri JM, Donohue K, Paskett ED. Exercise and dietary change after diagnosis and cancer-related symptoms in long-term survivors of breast cancer: CALGB 79804. Psycho-Oncology. 2009:18(2):128-33.

49. Jacobs DR, Tapsell LC. Food synergy: the key to a healthy diet. Proc Nutr Soc. 2013;72(2):200-6.

50. Olsson ME, Andersson CS, Oredsson S, Berglund RH, Gustavsson K-E. Antioxidant levels and inhibition of cancer cell proliferation in vitro by extracts from organically and conventionally cultivated strawberries. J Agric Food Chem. 2006;54(4):1248-55.

51. Kazimierczak R, Hallmann E, Lipowski J, Drela N, Kowalik A, Püssa T, Matt D, Luik A, Gozdowski D, Rembiałkowska E. Beetroot (Beta Vulgaris L.) and naturally fermented beetroot juices from organic and conventional production: metabolomics, antioxidant levels and anticancer activity. J Sci Food Agric. 2014;94(13):2618-29.

52. Velimirov A, Huber M, Lauridsen C, Rembiałkowska E, Seidel K, Bügel S. Feeding trials in organic food quality and health research. J Sci Food Agric. 2010;90(2):175-82.

53. Huber $M$, van de Vijver LP, Parmentier H, Savelkoul H, Coulier L, Wopereis $S$, Verheij E, van der Greef J, Nierop D, Hoogenboom RA. Effects of organically and conventionally produced feed on biomarkers of health in a chicken model. Br J Nutr. 2010;103(5):663-76.
54. Huber MAS, Coulier L, Wopereis S, Savelkoul H, Nierop D, Hoogenboom R. Enhanced catch-up growth after a challenge in animals on organic feed. Paris: International Conference on Nutrition \& Growth; 2012.

55. Huber M, Knottnerus JA, Green L, Hvd H, Jadad AR, Kromhout D, Leonard B, Lorig K, Loureiro MI, JWMvd M, et al. How should we define health? BMJ. 2011;343

56. Jensen MM, Jorgensen $\mathrm{H}$, Halekoh U, Olesen JE, Lauridsen C. Can agricultural cultivation methods influence the healthfulness of crops for foods? J Agric Food Chem. 2012;60(25):6383-90.

57. Srednicka-Tober D, Baranski M, Gromadzka-Ostrowska J, Skwarlo-Sonta K, Rembialkowska E, Hajslova J, Schulzova V, Cakmak I, Ozturk L, Krolikowski T, et al. Effect of crop protection and fertilization regimes used in organic and conventional production systems on feed composition and physiological parameters in rats. J Agric Food Chem. 2013;61(5):1017-29.

58. Finamore A, Britti MS, Roselli M, Bellovino D, Gaetani S, Mengheri E. Novel approach for food safety evaluation. Results of a pilot experiment to evaluate organic and conventional foods. J Agric Food Chem. 2004;52(24): 7425-31.

59. Jensen MM, Halekoh $U$, Stokes $C R$, Lauridsen C. Effect of maternal intake of organically or conventionally produced feed on oral tolerance development in offspring rats. J Agric Food Chem. 2013;61(20):4831-8.

60. Roselli M, Finamore A, Brasili E, Capuani G, Kristensen HL, Micheloni C, Mengheri E. Impact of organic and conventional carrots on intestinal and peripheral immunity. J Sci Food Agric. 2012;92(14):2913-22.

61. van Bruggen AH, Gamliel A, Finckh MR. Plant disease management in organic farming systems. Pest Manag Sci. 2016;72(1):30-44.

62. Zehnder G, Gurr GM, Kuhne S, Wade MR, Wratten SD, Wyss E. Arthropod pest management in organic crops. Annu Rev Entomol. 2007:52:57-80.

63. Garibaldi LA, Carvalheiro LG, Vaissiere BE, Gemmill-Herren B, Hipolito J, Freitas BM, Ngo HT, Azzu N, Saez A, Astrom J, et al. Mutually beneficial pollinator diversity and crop yield outcomes in small and large farms. Science. 2016:351(6271):388-91.

64. Gurr GM, Lu Z, Zheng X, Xu H, Zhu P, Chen G, Yao X, Cheng J, Zhu Z, Catindig $J$, et al. Multi-country evidence that crop diversification promotes ecological intensification of agriculture. Nat Plants. 2016:2:16014.

65. European Commission: COMMISSION REGULATION (EU) No 1107/2009 of 21 October 2009 concerning the placing of plant protection products on the market and repealing Council Directives 79/117/EEC and 91/414/EEC. In: Off J Eur Union 2009.

66. European Commission: EU pesticides database; 2017. ec.europa.eu/food/ plant/pesticides/eu-pesticides-database/.

67. Government report/policy document. French Ministry of Agriculture, Agrifood and Forestry. Plan Ecophyto II. http://agriculture.gouv.fr/sites/ minagri/files/151022_ecophyto.pdf. Accessed 11 Sept 2017.

68. Mallory EB, Halberg N, Andreasen L, Delate K, Ngouajio M. Innovations in organic food systems for sustainable production and ecosystem services: an introduction to the special issue of sustainable agriculture research. Sustain Agric Res. 2015;4(3):1.

69. Beck A, Alexander C, Eduardo H, Anna Maria K, Koopmans J, Micheloni C, Moeskops C, Niggli B, Urs P, Ilse A, Susanne and Rasmussen. TP Organics: Strategic research and innovation agenda for organic food and farming. Belgium. 2014.

70. International Centre for Research in Organic Food Systems (ICROFS): $\varnothing$ kologiens bidrag til samfundsgoder (the contribution of organic farming to public goods in Denmark, in Danish). 2015.

71. Gustaf Forsberg: Control of cereal seed-borne diseases by hot humid air seed treatment, vol. 443; 2004.

72. Forsberg G. Control of cereal seed-borne diseases by hot humid air seed treatment. Diss. Swedish university of Agricultural Sciences, SLU. Uppsala, Sweden. 2003;2003:130-5. ISBN 91-576-6496-X.

73. Lantmännen opens the most modern seed factory in Europe [http://lantmannen.com/en/about-lantmannen/press-and-publications/ news/news-page/news/lantmannen-opens-the-most-modern-seedfactory-in-europe/2196161].

74. European Food Safety Authority. The 2013 European Union Report on Pesticide Residues in Food. EFSA Journal. 2015;13:3.

75. European Food Safety Agency. The 2014 European Union report on pesticide residues in food. EFSA J. 2015;13(3):4038.

76. European Food Safety Agency. The 2015 European Union report on pesticide residues in food. EFSA J. 2017;15(4):4791. 
77. Kortenkamp A, Backhaus T, Faust M. State of the art report on mixture toxicity. In., vol. study 070307/2007/485103/ETU/D.1. European Commission: Brussels; 2009.

78. Beckman K: Exponering för resthalter av pesticider i konventionellt odlade frukter, bär och grönsaker inom EU och i tredje land jämfört med konventionellt odlade i Sverige samt ekologiskt odlade. (Exposure for pesticide residues in conventionally grown fruits, berries and vegetables from the EU and third countries, compared to conventionally grown products from Sweden and to organically grown products, in Swedish). Bachelor thesis. 2015.

79. European Commission, Directorate-General for Health and Food Safety: Final report of an audit carried out in Germany from 07 September 2015 to 11 September 2015 in order to evaluate pesticide residue controls in organic production. 2015.

80. CDC. Fourth National Report on human exposure to environmental chemicals, opdated tables september 2013. Washington: Centers for Disease Control and Prevention (CDC); 2013.

81. Viel JF, Warembourg C, Le Maner-Idrissi G, Lacroix A, Limon G, Rouget F, Monfort C, Durand G, Cordier S, Chevrier C. Pyrethroid insecticide exposure and cognitive developmental disabilities in children: the PELAGIE motherchild cohort. Environ Int. 2015;82:69-75.

82. Cartier C, Warembourg C, Le Maner-Idrissi G, Lacroix A, Rouget F, Monfort C, Limon G, Durand G, Saint-Amour D, Cordier S, et al. Organophosphate insecticide metabolites in prenatal and childhood urine samples and intelligence scores at 6 years of age: results from the mother-child PELAGIE cohort (France). Environ Health Perspect. 2016;124(5):674-80.

83. Fréry N, Guldner L, Saoudi A, Garnier R, Zeghnoun A, Bibondo M. Exposition de la population française aux substances chimiques de l'environnement. Polychlorobiphényles (PCB-NDL) et pesticides. In: Exposure of the French population to environmental chemicals. Volume 2 - Polychlorobiphenyls (NDL-PCBs) and pesticides, in French, vol. 2. Saint-Maurice: Institut de veille sanitaire; 2013.

84. Heudorf U, Butte W, Schulz C, Angerer J. Reference values for metabolites of pyrethroid and organophosphorous insecticides in urine for human biomonitoring in environmental medicine. Int J Hyg Environ Health. 2006; 209(3):293-9.

85. Spaan S, Pronk A, Koch HM, Jusko TA, Jaddoe WW, Shaw PA, Tiemeier HM, Hofman A, Pierik FH, Longnecker MP. Reliability of concentrations of organophosphate pesticide metabolites in serial urine specimens from pregnancy in the generation R study. J Expo Sci Environ Epidemiol. 2015; 25(3):286-94.

86. Roca M, Miralles-Marco A, Ferre J, Perez R, Yusa V. Biomonitoring exposure assessment to contemporary pesticides in a school children population of Spain. Environ Res. 2014;131C:77-85.

87. Croes K, Den Hond E, Bruckers L, Govarts E, Schoeters G, Covaci A, Loots I, Morrens B, Nelen V, Sioen I, et al. Endocrine actions of pesticides measured in the Flemish environment and health studies (FLEHS I and II). Environ Sci Pollut Res Int. 2015;22(19):14589-99.

88. Wielgomas B, Nahorski W, Czarnowski W. Urinary concentrations of pyrethroid metabolites in the convenience sample of an urban population of northern Poland. Int J Hyg Environ Health. 2013;216(3):295-300.

89. Mørck T, Andersen H, Knudsen L: Organophosphate metabolites in urine samples from Danish children and women - measured in the Danish DEMOCOPHES population. Danish Environmental Protection Agency. 2017.

90. Tyler CR, Beresford N, van der Woning M, Sumpter JP, Thorpe K Metabolism and environmental degradation of pyrethroid insecticides produce compounds with endocrine activities. Environ Toxicol Chem. Copenhagen. 2000;19(4):801-9.

91. Lu C, Toepel K, Irish R, Fenske RA, Barr DB, Bravo R. Organic diets significantly lower Children's dietary exposure to Organophosphorus pesticides. Environ Health Perspect. 2006;114(2):260-3.

92. Oates $L$, Cohen M, Braun L, Schembri A, Taskova R. Reduction in urinary organophosphate pesticide metabolites in adults after a week-long organic diet. Environ Res. 2014;132(0):105-11.

93. Bradman A, Quiros-Alcala L, Castorina R, Aguilar Schall R, Camacho J, Holland NT, Barr DB, Eskenazi B. Effect of organic diet intervention on pesticide exposures in young children living in low-income urban and agricultural communities. Environ Health Perspect. 2015;123(10): 1086-93.

94. Ye M, Beach J, Martin JW, Senthilselvan A. Associations between dietary factors and urinary concentrations of organophosphate and pyrethroid metabolites in a Canadian general population. Int J Hyg Environ Health. 2015;218(7):616-26.

95. Curl CL, Beresford SA, Fenske RA, Fitzpatrick AL, Lu C, Nettleton JA, Kaufman JD. Estimating pesticide exposure from dietary intake and organic food choices: the multi-ethnic study of atherosclerosis (MESA). Environ Health Perspect. 2015;123(5):475-83.

96. Goodson WH 3rd, Lowe L, Carpenter DO, Gilbertson M, Manaf Ali A, Lopez de Cerain Salsamendi A, Lasfar A, Carnero A, Azqueta A, Amedei A, et al. Assessing the carcinogenic potential of low-dose exposures to chemical mixtures in the environment: the challenge ahead. Carcinogenesis. 2015; 36(Suppl 1):S254-96.

97. Kortenkamp A. Low dose mixture effects of endocrine disrupters and their implications for regulatory thresholds in chemical risk assessment. Curr Opin Pharmacol. 2014;19:105-11.

98. Jacobsen PR, Axelstad M, Boberg J, Isling LK, Christiansen S, Mandrup KR, Berthelsen LO, Vinggaard AM, Hass U. Persistent developmental toxicity in rat offspring after low dose exposure to a mixture of endocrine disrupting pesticides. Reprod Toxicol. 2012;34(2):237-50.

99. Bjorling-Poulsen M, Andersen HR, Grandjean P. Potential developmental neurotoxicity of pesticides used in Europe. Environ Health. 2008;7:50.

100. Beronius A, Johansson N, Rudén C, Hanberg A. The influence of study design and sex-differences on results from developmental neurotoxicity studies of bisphenol a, implications for toxicity testing. Toxicology. 2013;311(1-2):13-26.

101. Tweedale T, Lysimachou A, Muilerman H. Missed \& Dismissed - pesticide regulators ignore the legal obligation to use independent science for deriving safe exposure levels. Brussels: PAN Europe; 2014.

102. Decision in case $12 / 2013 /$ MDC on the practices of the European Commission regarding the authorisation and placing on the market of plant protection products (pesticides), www.ombudsman.europa.eu/cases/ decision.faces/en/64069/html.bookmark, accessed 2016-03-15.

103. Chiu YH, Gaskins AJ, Williams PL, Mendiola J, Jorgensen N, Levine H, Hauser R, Swan SH, Chavarro JE, European Ombudsman. Intake of fruits and vegetables with low-to-moderate pesticide residues is positively associated with semen-quality parameters among young healthy men. J Nutr. 2016; 146(5):1084-92.

104. Choi AL, Cordier S, Weihe P, Grandjean P. Negative confounding in the evaluation of toxicity: the case of methylmercury in fish and seafood. Crit Rev Toxicol. 2008;38(10):877-93.

105. Ntzani EE, Chondrogiorgi M, Ntritsos G, Evangelou E, Tzoulaki I: Literature review on epidemiological studies linking exposure to pesticides and health effects. EFSA Supporting Publication. 2013:159.

106. Moisan F, Spinosi J, Delabre L, Gourlet V, Mazurie JL, Benatru I, Goldberg M, Weisskopf MG, Imbernon E, Tzourio C, et al. Association of Parkinson's disease and its subtypes with agricultural pesticide exposures in men: a case-control study in France. EFSA Supporting Publication. 2013;10(10):EN497. 159 pp.

107. Van Maele-Fabry G, Hoet P, Vilain F, Lison D. Occupational exposure to pesticides and Parkinson's disease: a systematic review and meta-analysis of cohort studies. Environ Int. 2012;46:30-43.

108. Starling AP, Umbach DM, Kamel F, Long S, Sandler DP, Hoppin JA. Pesticide use and incident diabetes among wives of farmers in the agricultural health study. Occup Environ Med. 2014;71(9):629-35.

109. Dyck R, Karunanayake C, Pahwa P, Hagel L, Lawson J, Rennie D, Dosman J. Prevalence, risk factors and co-morbidities of diabetes among adults in rural Saskatchewan: the influence of farm residence and agriculture-related exposures. BMC Public Health. 2013;13:7.

110. Schinasi L, Leon ME. Non-Hodgkin lymphoma and occupational exposure to agricultural pesticide chemical groups and active ingredients: a systematic review and meta-analysis. Int J Environ Res Public Health. 2014; 11(4):4449-527.

111. Van Maele-Fabry G, Hoet P, Lison D. Parental occupational exposure to pesticides as risk factor for brain tumors in children and young adults: a systematic review and meta-analysis. Environ Int. 2013;56:19-31.

112. Van Maele-Fabry G, Lantin AC, Hoet P, Lison D. Residential exposure to pesticides and childhood leukaemia: a systematic review and meta-analysis. Environ Int. 2011;37(1):280-91.

113. Chen M, Chang CH, Tao L, Lu C. Residential exposure to pesticide during childhood and childhood cancers: a meta-analysis. Pediatrics. 2015;136(4): 719-29.

114. Andersen HR, Schmidt IM, Grandjean P, Jensen TK, Budtz-Jorgensen E, Kjaerstad MB, Baelum J, Nielsen JB, Skakkebaek NE, Main KM. Impaired 
reproductive development in sons of women occupationally exposed to pesticides during pregnancy. Environ Health Perspect. 2008;116(4): 566-72.

115. Andersen HR, Debes F, Wohlfahrt-Veje C, Murata K, Grandjean P. Occupational pesticide exposure in early pregnancy associated with sexspecific neurobehavioral deficits in the children at school age. Neurotoxicol Teratol. 2015:47:1-9

116. Wohlfahrt-Veje C, Andersen HR, Schmidt IM, Aksglaede L, Sorensen K, Juul A, Jensen TK, Grandjean P, Skakkebaek NE, Main KM. Early breast development in girls after prenatal exposure to non-persistent pesticides. Int J Androl. 2012;35(3):273-82.

117. Wohlfahrt-Veje C, Andersen HR, Jensen TK, Grandjean P, Skakkebaek NE, Main KM. Smaller genitals at school age in boys whose mothers were exposed to non-persistent pesticides in early pregnancy. Int J Androl. 2012; 35(3):265-72.

118. Wohlfahrt-Veje C, Main KM, Schmidt IM, Boas M, Jensen TK, Grandjean P, Skakkebaek NE, Andersen HR. Lower birth weight and increased body fat at school age in children prenatally exposed to modern pesticides: a prospective study. Environ Health. 2011;10:79.

119. Grandjean P, Landrigan PJ. Developmental neurotoxicity of industrial chemicals. Lancet. 2006:368(9553):2167-78.

120. Young JG, Eskenazi B, Gladstone EA, Bradman A, Pedersen L, Johnson C, Barr DB, Furlong CE, Holland NT. Association between in utero organophosphate pesticide exposure and abnormal reflexes in neonates. Neurotoxicology. 2005;26(2):199-209.

121. Eskenazi B, Marks AR, Bradman A, Harley K, Barr DB, Johnson C, Morga N, Jewell NP. Organophosphate pesticide exposure and neurodevelopment in young Mexican-American children. Environ Health Perspect. 2007;115(5):792-8.

122. Marks AR, Harley K, Bradman A, Kogut K, Barr DB, Johnson C, Calderon N, Eskenazi B. Organophosphate pesticide exposure and attention in young Mexican-American children: the CHAMACOS study. Environ Health Perspect. 2010;118(12):1768-74.

123. Bouchard MF, Chevrier J, Harley KG, Kogut K, Vedar M, Calderon N, Trujillo C, Johnson C, Bradman A, Barr DB, et al. Prenatal exposure to organophosphate pesticides and IQ in 7-year-old children. Environ Health Perspect. 2011;119(8):1189-95.

124. Engel SM, Wetmur J, Chen J, Zhu C, Barr DB, Canfield RL, Wolff MS. Prenatal exposure to organophosphates, paraoxonase 1, and cognitive development in childhood. Environ Health Perspect. 2011;119(8):1182-8.

125. Rauh VA, Garfinkel R, Perera FP, Andrews HF, Hoepner L, Barr DB, Whitehead R, Tang D, Whyatt RW. Impact of prenatal chlorpyrifos exposure on neurodevelopment in the first 3 years of life among inner-city children. Pediatrics. 2006;118(6):e1845-59.

126. Rauh V, Arunajadai S, Horton M, Perera F, Hoepner L, Barr DB, Whyatt R. Seven-year neurodevelopmental scores and prenatal exposure to chlorpyrifos, a common agricultural pesticide. Environ Health Perspect. 2011 119(8):1196-201.

127. Rauh VA, Perera FP, Horton MK, Whyatt RM, Bansal R, Hao X, Liu J, Barr DB, Slotkin TA, Peterson BS. Brain anomalies in children exposed prenatally to a common organophosphate pesticide. Proc Natl Acad Sci U S A. 2012; 109(20):7871-6

128. Rauh VA, Garcia WE, Whyatt RM, Horton MK, Barr DB, Louis ED. Prenatal exposure to the organophosphate pesticide chlorpyrifos and childhood tremor. Neurotoxicology. 2015;51:80-6.

129. Grandjean P, Landrigan PJ. Neurobehavioural effects of developmental toxicity. Lancet Neurol. 2014;13(3):330-8.

130. Gonzalez-Alzaga B, Lacasana M, Aguilar-Garduno C, Rodriguez-Barranco M, Ballester F, Rebagliato M, Hernandez AF. A systematic review of neurodevelopmental effects of prenatal and postnatal organophosphate pesticide exposure. Toxicol Lett. 2014;230(2):104-21.

131. Ross SM, McManus IC, Harrison V, Mason O. Neurobehavioral problems following low-level exposure to organophosphate pesticides: a systematic and meta-analytic review. Crit Rev Toxicol. 2013:43(1):21-44

132. Munoz-Quezada MT, Lucero BA, Barr DB, Steenland K, Levy K, Ryan PB, Iglesias V, Alvarado S, Concha C, Rojas E, et al. Neurodevelopmental effects in children associated with exposure to organophosphate pesticides: a systematic review. Neurotoxicology. 2013;39C:158-68.

133. Bouchard MF, Bellinger DC, Wright RO, Weisskopf MG. Attention-deficit/ hyperactivity disorder and urinary metabolites of organophosphate pesticides. Pediatrics. 2010;125(6):e1270-7.
134. Wagner-Schuman M, Richardson JR, Auinger P, Braun JM, Lanphear BP, Epstein JN, Yolton K, Froehlich TE. Association of pyrethroid pesticide exposure with attention-deficit/hyperactivity disorder in a nationally representative sample of U.S. children. Environ Health. 2015;14(1):44.

135. Quiros-Alcala L, Mehta S, Eskenazi B. Pyrethroid pesticide exposure and parental report of learning disability and attention deficit/hyperactivity disorder in U.S. children: NHANES 1999-2002. Environ Health Perspect. 2014; 122(12):1336-42

136. Oulhote Y, Bouchard MF. Urinary metabolites of organophosphate and Pyrethroid pesticides and behavioral problems in Canadian children. Environ Health Perspect. 2013;121(11-12):1378-84.

137. Viel JF, Rouget F, Warembourg C, Monfort C, Limon G, Cordier S, Chevrier C: Behavioural disorders in 6-year-old children and pyrethroid insecticide exposure: the PELAGIE mother-child cohort. Occup Environ Med 2017.

138. Yolton $K, X u$ Y, Sucharew H, Succop P, Altaye M, Popelar A, Montesano MA, Calafat AM, Khoury JC. Impact of low-level gestational exposure to organophosphate pesticides on neurobehavior in early infancy: a prospective study. Environ Health. 2013;12(1):79.

139. McKelvey W, Jacobson JB, Kass D, Barr DB, Davis M, Calafat AM, Aldous KM: Population-based biomonitoring of exposure to organophosphate and Pyrethroid pesticides in new York City. Environ Health Perspect. 2013.

140. Bellanger M, Demeneix B, Grandjean P, Zoeller RT, Trasande L. Neurobehavioral Deficits, Diseases and Associated Costs of Exposure to Endocrine Disrupting Chemicals in the European Union. J Clin Endocrin Metab. 2015; https://doi.org/10.1210/jc.2014-4323.

141. European Food Safety Authority: Final addendum to the art. 21 review on chlorpyrifos - public version. 2014.

142. Rapporteur Member State Spain. European Commission: Commission Regulation (EU) 2016/60 of 19 January 2016 amending Annexes II and III to Regulation (EC) No 396/2005 of the European Parliament and of the Council as regards maximum residue levels for chlorpyrifos in or on certain products. In: Off J Eur Union 2016. http://www.efsa.europa.eu/.

143. European Food Safety Authority (EFSA). Refined risk assessment regarding certain maximum residue levels (MRLs) of concern for the active substance chlorpyrifos. 2015:13(6):4142.

144. European Food Safety Authority: Conclusion on the peer review of the pesticide human health risk assessment of the active substance chlorpyrifos. 2014;12(4):3640

145. Principles of organic agriculture, http://www.ifoam.bio/en/organiclandmarks/principles-organic-agriculture, accessed 2016-04-18.

146. Seufert V, Ramankutty N, Foley JA. Comparing the yields of organic and conventional agriculture. Nature. 2012;485(7397):229-32.

147. van Huylenbroek G, Mondelaers K, Aertsens J, Mondelaers K, Aertsens J, van Huylenbroeck G. A meta-analysis of the differences in environmental impacts between organic and conventional farming. $\mathrm{Br}$ Food J. 2009:111(10):1098-119.

148. Mie A, Laursen K, Åberg KM, Forshed J, Lindahl A, Thorup-Kristensen K, Olsson $M$, Knuthsen $P$, Larsen E, Husted S. Discrimination of conventional and organic white cabbage from a long-term field trial study using untargeted LC-MS-based metabolomics. Anal Bioanal Chem. 2014:406(12):2885-97.

149. Novotná H, Kmiecik O, Gałązka M, Krtková V, Hurajová A, Schulzová V, Hallmann E, Rembiałkowska E, Hajšlová J. Metabolomic fingerprinting employing DART-TOFMS for authentication of tomatoes and peppers from organic and conventional farming. Food Addit Contam Part A Chem Anal Control Expo Risk Assess. 2012;29(9):1335-46.

150. Vallverdú-Queralt A, Medina-Remón A, Casals-Ribes I, Amat M, Lamuela-Raventós RM. A Metabolomic approach differentiates between conventional and organic ketchups. J Agric Food Chem. 2011:59(21):11703-10.

151. Röhlig RM, Engel K-H. Influence of the input system (conventional versus organic farming) on metabolite profiles of maize (Zea Mays) kernels. J Agric Food Chem. 2010;58(5):3022-30.

152. Chen P, Harnly JM, Lester GE. Flow injection mass spectral fingerprints demonstrate chemical differences in Rio red grapefruit with respect to year, harvest time, and conventional versus organic farming. J Agric Food Chem. 2010;58(8):4545-53.

153. Lehesranta SJ, Koistinen KM, Massat N, Davies HV, Shepherd LV, McNicol JW, Cakmak I, Cooper J, Luck L, Karenlampi SO, et al. Effects of agricultural production systems and their components on protein profiles of potato tubers. Proteomics. 2007;7(4):597-604. 
154. Nawrocki A, Thorup-Kristensen K, Jensen ON. Quantitative proteomics by $2 \mathrm{DE}$ and MALDI MS/MS uncover the effects of organic and conventional cropping methods on vegetable products. J Proteome. 2011;74(12):2810-25.

155. Lu CG, Hawkesford MJ, Barraclough PB, Poulton PR, Wilson ID, Barker GL, Edwards KJ. Markedly different gene expression in wheat grown with organic or inorganic fertilizer. Proc R Soc Lond Ser BBiol Sci. 2005;272(1575): 1901-8.

156. van Dijk JP, Cankar K, Hendriksen PJM, Beenen HG, Zhu M, Scheffer S, Shepherd LVT, Stewart D, Davies HV, Leifert C, et al. The identification and interpretation of differences in the Transcriptomes of organically and conventionally grown potato tubers. J Agric Food Chem. 2012; 60(9):2090-101.

157. Dangour AD, Dodhia SK, Hayter A, Allen E, Lock K, Uauy R. Nutritional quality of organic foods: a systematic review. Am J Clin Nutr. 2009;90(3):680-5.

158. Brandt K, Leifert C, Sanderson R, Seal CJ. Agroecosystem management and nutritional quality of plant foods: the case of organic fruits and vegetables. Crit Rev Plant Sci. 2011;30(1-2):177-97.

159. Barański M, Średnicka-Tober D, Volakakis N, Seal C, Sanderson R, Stewart GB, Benbrook C, Biavati B, Markellou E, Giotis C, et al. Higher antioxidant and lower cadmium concentrations and lower incidence of pesticide residues in organically grown crops: a systematic literature review and meta-analyses. Br J Nutr. 2014;112(05):794-811.

160. Bindraban PS, Dimkpa C, Nagarajan L, Roy A, Rabbinge R. Revisiting fertilisers and fertilisation strategies for improved nutrient uptake by plants. Biol Fertil Soils. 2015:51(8):897-911.

161. Wiesler F. Nutrition and quality. In: Marschner's mineral nutrition of higher plants. Third ed. San Diego: Academic Press; 2012. p. 271-82.

162. Huber D, Römheld V, Weinmann M. Relationship between nutrition, plant diseases and pests. In: Marschner $P$, editor. Marschners mineral nutrition of higher plants. third ed; 2012. p. 283-98.

163. Güsewell S. N:P ratios in terrestrial plants: variation and functional significance. New Phytol. 2004;164(2):243-66.

164. Del Rio D, Rodriguez-Mateos A, Spencer JP, Tognolini M, Borges G, Crozier A. Dietary (poly)phenolics in human health: structures, bioavailability, and evidence of protective effects against chronic diseases. Antioxid Redox Signal. 2013;18(14):1818-92.

165. Treutter D. Managing phenol contents in crop plants by Phytochemical farming and breeding — visions and constraints. Int J Mol Sci. 2010;11(3): 807-57.

166. Akesson A, Barregard L, Bergdahl IA, Nordberg GF, Nordberg M, Skerfving S. Non-renal effects and the risk assessment of environmental cadmium exposure. Environ Health Perspect. 2014;122(5):431-8.

167. Grant CA. Influence of phosphate fertilizer on cadmium in agricultural soils and crops. In: Phosphate in Soils: Interaction with Micronutrients, Radionuclides and Heavy Metals, vol. 2; 2015. p. 123

168. EFSA Panel on Contaminants in the Food Chain. Cadmium in food. Scientific opinion of the panel on contaminants in the food chain on a request from the European Commission on cadmium in food. EFSA J. 2009; 980:1-139.

169. de Meeûs C, Eduljee $\mathrm{GH}$, Hutton M. Assessment and management of risks arising from exposure to cadmium in fertilisers. I. Sci Total Environ. 2002; 291(1-3):167-87.

170. Directorate-General for Enterprise and Industry (European Commission), Environmental Resources Management. European Commission: Analysis and conclusions from member States' assessment of the risk to health and the environment from cadmium in Fertilisers. 2001. https:/publications.europa.eu/ en/publication-detail/-/publication/6cfa95d3-2346-4c9f-8a06-35a5a0befoff/ language-en.

171. Nziguheba G, Smolders E. Inputs of trace elements in agricultural soils via phosphate fertilizers in European countries. Sci Total Environ. 2008;390(1): 53-7.

172. Kratz S, Schnug E. Schwermetalle in P-Düngern (Heavy metals in P fertilisers, in German). Landbauforschung Völkenrode Spec. 2005;286:37-45.

173. Baranski M, Steward G, Leifert C: Personal communication. 2016.

174. Laursen KH, Schjoerring JK, Olesen JE, Askegaard M, Halekoh U, Husted S. Multielemental fingerprinting as a tool for authentication of organic wheat, barley, faba bean, and potato. J Agric Food Chem. 2011;59(9):4385-96.

175. Gundersen V, Bechmann IE, Behrens A, Sturup S. Comparative investigation of concentrations of major and trace elements in organic and conventional
Danish agricultural crops. 1. Onions (Allium Cepa Hysam) and peas (Pisum Sativum ping pong). J Agric Food Chem. 2000;48(12):6094-102.

176. Jones $K$, Johnston A. Cadmium in cereal grain and herbage from long-term experimental plots at Rothamsted UK. Environ Pollut. 1989:57(3):199-216.

177. Christensen BT, Elsgaard L. Handelsgødnings indflydelse på afgrøders indhold af arsen, bly, cadmium, krom, kviksølv og nikkel (The influence of mineral fertilisers on the crop's content of arsenic, lead, cadmium, chromium and nickel, in Danish). Tjele: DCA - Nationalt Center for Fødevarer og Jordbrug; 2013.

178. Schnug E, Haneklaus N: Uranium in phosphate fertilizers-review and outlook. Uranium-past and future challenges. Cham: Springer; 2015;123-130.

179. Kratz S, Knappe F, Schnug E. Uranium balances in agroecosystems. In: Loads and fate of fertilizer-derived uranium Leiden: Backhuys; 2008. p. 179-90.

180. Bigalke M, Ulrich A, Rehmus A, Keller A. Accumulation of cadmium and uranium in arable soils in Switzerland. Environ Pollut. 2017;221:85-93.

181. Liesch T, Hinrichsen S, Goldscheider N. Uranium in groundwater-fertilizers versus geogenic sources. Sci Total Environ. 2015;536:981-95.

182. Birke M, Rauch U, Lorenz $\mathrm{H}$. Uranium in stream and mineral water of the Federal Republic of Germany. Environ Geochem Health. 2009;31(6):693-706.

183. Karlsson I, Friberg $H$, Steinberg C, Persson P. Fungicide effects on fungal community composition in the wheat phyllosphere. PLoS One. 2014:9(11):e111786

184. Karlsson I, Friberg H, Kolseth AK, Steinberg C, Persson P. Organic farming increases richness of fungal taxa in the wheat phyllosphere. Mol Ecol. 2017;

185. Bernhoft A, Torp M, Clasen PE, Loes AK, Kristoffersen AB. Influence of agronomic and climatic factors on Fusarium infestation and mycotoxin contamination of cereals in Norway. Food Addit Contam Part A Chem Anal Control Expo Risk Assess. 2012;29(7):1129-40.

186. Kabak B, Dobson AD, Var I. Strategies to prevent mycotoxin contamination of food and animal feed: a review. Crit Rev Food Sci Nutr. 2006:46(8):593-619.

187. European Food Safety Authority. Risks to human and animal health related to the presence of deoxynivalenol and its acetylated and modified forms in food and feed. EFSA J. 2017;15(9):4718.

188. Warnecke S, Paulsen HM, Schulz F, Rahmann G. Greenhouse gas emissions from enteric fermentation and manure on organic and conventional dairy farms - an analysis based on farm network data. Org Agric. 2014;4(4):285-93

189. Palupi E, Jayanegara A, Ploeger A, Kahl J. Comparison of nutritional quality between conventional and organic dairy products: a meta-analysis. J Sci Food Agric. 2012;92(14):2774-81.

190. Woods VB, Fearon AM. Dietary sources of unsaturated fatty acids for animals and their transfer into meat, milk and eggs: a review. Livest Sci. 2009;126(1-3):1-20.

191. Khiaosa-ard R, Kreuzer M, Leiber F. Apparent recovery of C18 polyunsaturated fatty acids from feed in cow milk: a meta-analysis of the importance of dietary fatty acids and feeding regimens in diets without fat supplementation. J Dairy Sci. 2015:98(9):6399-414.

192. Średnicka-Tober D, Barański M, Seal CJ, Sanderson R, Benbrook C, Steinshamn H, Gromadzka-Ostrowska J, Rembiałkowska E, Skwarło-Sońta K, Eyre M. Higher PUFA and n-3 PUFA, conjugated linoleic acid, a-tocopherol and iron, but lower iodine and selenium concentrations in organic milk: a systematic literature review and meta-and redundancy analyses. Br J Nutr. 2016:1-18.

193. Schwendel BH, Wester TJ, Morel PCH, Tavendale MH, Deadman C, Shadbolt NM, Otter DE. Organic and conventionally produced milk - an evaluation of factors influencing milk composition. J Dairy Sci. 2015; 98(2):721-46.

194. Anderson KE. Comparison of fatty acid, cholesterol, and vitamin a and $\mathrm{E}$ composition in eggs from hens housed in conventional cage and range production facilities. Poult Sci. 2011:90(7):1600-8.

195. Mugnai C, Sossidou EN, Dal Bosco A, Ruggeri S, Mattioli S, Castellini C. The effects of husbandry system on the grass intake and egg nutritive characteristics of laying hens. J Sci Food Agric. 2014;94(3):459-67.

196. Rakonjac S, Bogosavljević-Bošković S, Pavlovski Z, Škrbić Z, Dosković V, Petrović $M$, Petričević $V$. Laying hen rearing systems: a review of chemical composition and hygienic conditions of eggs. World's Poult Sci J. 2014; 70(01):151-64

197. Średnicka-Tober D, Barański M, Seal C, Sanderson R, Benbrook C, Steinshamn H, Gromadzka-Ostrowska J, Rembiałkowska E, Skwarło-Sońta K, 
Eyre $\mathrm{M}$, et al. Composition differences between organic and conventional meat: a systematic literature review and meta-analysis. Br I Nutr. 2016; 115(06):994-1011.

198. Mie A, Kesse-Guyot E, Kahl J, Rembiałkowska E, Andersen HR, Grandjean P, Gunnarsson S: Human health implications of organic food and organic agriculture. www.europarl.europa.eu/RegData/etudes/STUD/2016/581922/ EPRS_STU(2016)581922_EN.pdf. In. Edited by European Parliament Parliamentary Research Services; 2016.

199. Wanders AJ, Alssema M, de Koning EJP, le Cessie S, de Vries JH, Zock PL, Rosendaal FR, Md H, de Mutsert R. Fatty acid intake and its dietary sources in relation with markers of type 2 diabetes risk: the NEO study. Eur J Clin Nutr. 2017;71(2):245-51.

200. van Valenberg HJF, Hettinga KA, Dijkstra J, Bovenhuis H, Feskens EJM. Concentrations of $n-3$ and $n-6$ fatty acids in Dutch bovine milk fat and their contribution to human dietary intake. J Dairy Sci. 2013;96(7): 4173-81.

201. Welch AA, Shakya-Shrestha S, Lentjes MA, Wareham NJ, Khaw KT. Dietary intake and status of $n-3$ polyunsaturated fatty acids in a population of fisheating and non-fish-eating meat-eaters, vegetarians, and vegans and the product-precursor ratio [corrected] of alpha-linolenic acid to long-chain n-3 polyunsaturated fatty acids: results from the EPIC-Norfolk cohort. Am J Clin Nutr. 2010;92(5):1040-51

202. Astorg P, Arnault N, Czernichow S, Noisette N, Galan P, Hercberg S. Dietary intakes and food sources of $n-6$ and n-3 PUFA in French adult men and women. Lipids. 2004;39(6):527-35.

203. EFSA Panel on Dietetic Products, Nutrition and Allergies: Scientific opinion on dietary reference values for fats, including saturated fatty acids, polyunsaturated fatty acids, monounsaturated fatty acids, trans fatty acids, and cholesterol. 2010.

204. Jakobsen MU, O'Reilly EJ, Heitmann BL, Pereira MA, Balter K, Fraser GE, Goldbourt U, Hallmans G, Knekt P, Liu S, et al. Major types of dietary fat and risk of coronary heart disease: a pooled analysis of 11 cohort studies. Am J Clin Nutr. 2009;89(5):1425-32.

205. Chen M, Li Y, Sun Q, Pan A, Manson JE, Rexrode KM, Willett WC, Rimm EB, Hu FB. Dairy fat and risk of cardiovascular disease in 3 cohorts of US adults. Am J Clin Nutr. 2016;104(5):1209-17.

206. Wang DD, Li Y, Chiuve SE, Stampfer MJ, Manson JE, Rimm EB, Willett WC, Hu FB. Association of Specific Dietary Fats with Total and Cause-Specific Mortality. JAMA Intern Med. 2016;176(8):1134-45.

207. de Souza RJ, Mente A, Maroleanu A, Cozma Al, Ha V, Kishibe T, Uleryk E, Budylowski P, Schunemann H, Beyene J, et al. Intake of saturated and trans unsaturated fatty acids and risk of all cause mortality, cardiovascular disease, and type 2 diabetes: systematic review and meta-analysis of observational studies. BMJ. 2015;351:h3978.

208. Gayet-Boyer C, Tenenhaus-Aziza F, Prunet C, Marmonier C, Malpuech-Brugere C, Lamarche B, Chardigny JM. Is there a linear relationship between the dose of ruminant trans-fatty acids and cardiovascular risk markers in healthy subjects: results from a systematic review and meta-regression of randomised clinical trials. Br J Nutr. 2014:112(12):1914-22

209. Lee SY, Pearce EN. Reproductive endocrinology: iodine intake in pregnancy-even a little excess is too much. Nat Rev Endocrinol. 2015;11(5):260-1.

210. Lazarus JH. lodine status in Europe in 2014. Eur Thyroid J. 2014;3(1):3-6.

211. Gartner R. Recent data on iodine intake in Germany and Europe. J Trace Elem Med Biol. 2016:37:85-9.

212. Aburto N, Abudou M, Candeias V, Wu T, Organization WH. Effect and safety of salt iodization to prevent iodine deficiency disorders: a systematic review with meta-analyses. Geneva: World Health Organization; 2014

213. Woolhouse M, Ward M, van Bunnik B, Farrar J. Antimicrobial resistance in humans, livestock and the wider environment. Philos Tran R Soc Lond B Biol Sci. 2015;370(1670):20140083

214. Silbergeld EK, Graham J, Price LB. Industrial food animal production, antimicrobial resistance, and human health. Annu Rev Public Health. 2008; 29:151-69.

215. Cully M. Public health: the politics of antibiotics. Nature. 2014;509(7498): S16-7.

216. European Food Safety Authority (EFSA). ECDC/EFSA/EMA second joint report on the integrated analysis of the consumption of antimicrobial agents and occurrence of antimicrobial resistance in bacteria from humans and food-producing animals. EFSA J. 2017;15(7):4872.
217. WHO. Strategic and technical advisory group on antimicrobial resistance (STAG-AMR): report of the fifth meeting, 23-24 November 2015, WHO Headquarters. Geneva: World Health Organization; 2016. p. 9.

218. Laxminarayan R, Duse A, Wattal C, Zaidi AKM, Wertheim HFL, Sumpradit N, Vlieghe E, Hara GL, Gould IM, Goossens H, et al. Antibiotic resistance-the need for global solutions. Lancet Infect Dis. 2013;13(12):1057-98.

219. Martinez JL. Environmental pollution by antibiotics and by antibiotic resistance determinants. Environ Pollut. 2009;157(11):2893-902.

220. Casewell M, Friis C, Marco E, McMullin P, Phillips I. The European ban on growth-promoting antibiotics and emerging consequences for human and animal health. J Antimicrob Chemother. 2003;52(2):159-61.

221. Hao H, Cheng G, lqbal Z, Ai X, Hussain HI, Huang L, Dai M, Wang Y, Liu Z, Yuan Z. Benefits and risks of antimicrobial use in food-producing animals. Front Microbiol. 2014;5:288.

222. Mather AE, Reid SWJ, Maskell DJ, Parkhill J, Fookes MC, Harris SR, Brown DJ, Coia JE, Mulvey MR, Gilmour MW, et al. Distinguishable epidemics of multidrug-resistant salmonella Typhimurium DT104 in different hosts. Science. 2013;341(6153):1514-7.

223. Mather AE, Matthews L, Mellor DJ, Reeve R, Denwood MJ, Boerlin P, Reid-Smith RJ, Brown DJ, Coia JE, Browning LM, et al. An ecological approach to assessing the epidemiology of antimicrobial resistance in animal and human populations. Proc R Soc Lond B Biol Sci. 2012; 279(1733):1630-9.

224. Bruckmeier K, Prutzer M. Swedish pig producers and their perspectives on animal welfare: a case study. Br Food J. 2007;109(11):906-18.

225. Andreasen CB, Spickler AR, Jones BE. Swedish animal welfare regulations and their impact on food animal production. J Am Vet Med A. 2005;227(1): 34-40.

226. European Food Safety Authority. Scientific opinion of the panel of animal health and welfare on the request from the Commission on the welfare of weaners and rearing pigs: effects of different space allowances and floor types. EFSA J. 2005:268:1-19.

227. European Food Safety Authority. Scientific opinion of the panel of animal health and welfare on the request from the Commission on animal health and welfare in fattening pigs in relation to housing and husbandry. EFSA Journal. 2007:564:1-14.

228. Kijlstra A, Eijck IAJM. Animal health in organic livestock production systems: a review. Wagening J Life Sci. 2006;54(1):77-94.

229. Hegelund L. Medicinforbrug og dødelighed i økologisk og konventionel slagtesvineproduktion (use of pharmaceuticals and mortality in organic and conventional pig production, in Danish). In: Sundhed og medicinforbrug hos økologiske og konventionelle slagtesvin; 2006. p. 13-6.

230. Wingstrand A, Struve T, Lundsby K, Vigre H, Emborg HD, Sørensen AlV, Jensen VF. Antibiotikaresistens og -forbrug i slagtesvineproduktionen (antibiotic resistance and use in pig production, in Danish). In: Fremtidens fødevaresikkerhed- Nye veje mod sikrere kød i Danmark. Denmark: Center for Bioetik og Risikovurdering; 2010. p. 98-106.

231. Bennedsgaard TW, Klaas IC, Vaarst M. Reducing use of antimicrobials experiences from an intervention study in organic dairy herds in Denmark. Livest Sci. 2010;131:183-92

232. Kuipers A, Koops W. Wemmenhove H. Antibiotic use in dairy herds in the Netherlands from 2005 to 2012. J Dairy Sci. 2016;99(2):1632-48.

233. Fall N, Emanuelson U. Milk yield, udder health and reproductive performance in Swedish organic and conventional dairy herds. J Dairy Res. 2009:76(4):402-10.

234. Landesamt fuer Natur Umwelt und Verbraucherschutz Nordrhein-Westfalen. Überarbeiteter Abschlussbericht. Evaluierung des Antibiotikaeinsatzes in der Hähnchenhaltung. In: Revised final report. Evaluation of antibiotic use in broiler production. In German; 2012. https://www.lanuv.nrw.de/fileadmin/lanuv/agrar/ tiergesundheit/arzneimittel/antibiotika/120403_Masthaehnchenstudie_ ueberarbeitung_Evaluation_Endfassung.pdf.

235. Snary E, Pleydell E, Munday D. Investigation of persistence of antimicrobial resistant organisms in broiler flocks: a mathematical model. UK: Veterinary Laboratories Agency; 2006.

236. Von Borell E, Sørensen JT. Organic livestock production in Europe: aims, rules and trends with special emphasis on animal health and welfare. Livest Prod Sci. 2004;90(1):3-9.

237. Hemme M, van Rennings L, Hartmann M, von Münchhausen C, Käsbohrer A Kreienbrock L. Antibiotikaeinsatz in der Nutztierhaltung in Deutschland. Erste Ergebnisse zu zeitlichen Trends im wissenschaftlichen Projekt "VetCAbSentinel" Antibiotic use in livestock production in Germany. First results of 
temporal trends in the scientific project "VetCAb-Sentinel" (in German). Deutsches Tierärzteblatt. 2016;4:516-20.

238. Katherine G, Callum H, Reeves H, Healey K, Coyne L, Teale C. UK Veterinary Antibiotic Resistance and Sales Surveillance (UK-VARSS). 2014. https://www. gov.uk/government/uploads/system/uploads/attachment_data/file/477788/ Optimised_version_-_VARSS_Report_2014_Sales_Resistance_.pdf

239. Persoons D, Dewulf J, Smet A, Herman L, Heyndrickx M, Martel A, Catry B, Butaye $P$, Haesebrouck F. Antimicrobial use in Belgian broiler production. Prev Vet Med. 2012;105(4):320-5.

240. Woolhouse MEJ, Ward MJ. Sources of antimicrobial resistance. Science. 2013;341(6153):1460-1.

241. European Food Safety Authority. SCIENTIFIC REPORT OF ECDC, EFSA AND EMA ECDC/EFSA/EMA first joint report on the integrated analysis of the consumption of antimicrobial agents and occurrence of antimicrobial resistance in bacteria from humans and food-producing animals. EFSA Journal. 2015;13(1)(4006):114.

242. Kemper N. Veterinary antibiotics in the aquatic and terrestrial environment Ecol Indic. 2008;8(1):1-13.

243. Aarestrup FM. Veterinary drug usage and antimicrobial resistance in bacteria of animal origin. Basic Clin Pharmacol Toxicol. 2005;96:271-81.

244. Österberg J, Wingstrand A, Jensen AN, Kerouanton A, Cibin V, Barco L, Denis $M$, Aabo S, Bengtsson B. Antibiotic resistance in Escherichia coli from pigs in organic and conventional farming in four European countries. PloS one. 2016;11(6):e0157049.

245. Sapkota AR, Kinney EL, George A, Hulet RM, Cruz-Cano R, Schwab KJ, Zhang G, Joseph SW. Lower prevalence of antibiotic-resistant salmonella on large-scale US conventional poultry farms that transitioned to organic practices. Sci Total Environ. 2014;476:387-92.

246. Leverstein-van Hall MA, Dierikx CM, Stuart JC, Voets GM, van den Munckhof MP, van Essen-Zandbergen A, Platteel T, Fluit AC, van de Sande-Bruinsma N, Scharinga J, et al. Dutch patients, retail chicken meat and poultry share the same ESBL genes, plasmids and strains. Clin Microbiol Infec. 2011;17(6):873-80.

247. de Neeling AJ, van den Broek MJM, Spalburg EC, van Santen-Verheuvel MG, Dam-Deisz WDC, Boshuizen HC, de Giessen AWV, van Duijkeren E, Huijsdens XW. High prevalence of methicillin resistant Staphylococcus Aureus in pigs. Vet Microbiol. 2007;122(3-4):366-72.

248. Fromm S, Beißwanger E, Käsbohrer A, Tenhagen B-A. Risk factors for MRSA in fattening pig herds - a meta-analysis using pooled data. Prev Vet Med. 2014;117(1):180-8

249. Aubry-Damon H, Grenet K, Sall-Ndiaye P, Che D, Cordeiro E, Bougnoux ME, Rigaud E, Le Strat Y, Lemanissier V, Armand-Lefevre L, et al. Antimicrobial resistance in commensal flora of pig farmers. Emerg Infect Dis. 2004;10(5): 873-9.

250. Armand-Lefevre L, Ruimy R, Andremont A. Clonal comparison of Staphylococcus Aureus isolates from healthy pig farmers, human controls, and pigs. Emerg Infect Dis. 2005;11(5):711-4

251. Gerzova L, Babak V, Sedlar K, Faldynova M, Videnska P, Cejkova D, Jensen AN, Denis M, Kerouanton A, Ricci A, et al. Characterization of antibiotic resistance gene abundance and microbiota composition in feces of organic and conventional pigs from four EU countries. PLOS One. 2015;10(7):e0132892.

252. Osterberg J, Wingstrand A, Nygaard Jensen A, Kerouanton A, Cibin V, Barco L, Denis M, Aabo S, Bengtsson B. Antibiotic resistance in Escherichia Coli from pigs in organic and conventional farming in four European countries. PLoS One. 2016;11(6):e0157049.

253. Gleeson BL, Collins AM. Under what conditions is it possible to produce pigs without using antimicrobials? Anim Prod Sci. 2015;55(12): 1424-31.

254. Tilman D, Clark M. Global diets link environmental sustainability and human health. Nature. 2014:515(7528):518-22.

255. United States Environmental Protection Agency (EPA): Literature Review on Neurodevelopment Effects \& FQPA Safety Factor Determination for the Organophosphate Pesticides. https://www.regulations.gov/ contentStreamer?documentld=EPA-HQ-OPP-2008-0119-0015\&contentType= pdf. In.; 2015. Accessed 19 Sept 2017.

256. Bourguet D, Guillemaud T: The hidden and external costs of pesticide use. In: Sustainable Agriculture Reviews. Cham: Springer; 2016;35-120.

257. Kahl J, Alborzi F, Beck A, Bugel S, Busscher N, Geier U, Matt D, Meischner T, Paoletti F, Pehme S, et al. Organic food processing: a framework for concept, starting definitions and evaluation. J Sci Food Agric. 2014;94(13): 2582-94.
258. Monteiro CA, Levy RB, Claro RM, de Castro IR, Cannon G. Increasing consumption of ultra-processed foods and likely impact on human health: evidence from Brazil. Public Health Nutr. 2011;14(1):5-13.

259. Fardet A, Rock E, Bassama J, Bohuon P, Prabhasankar P, Monteiro C, Moubarac JC, Achir N. Current food classifications in epidemiological studies do not enable solid nutritional recommendations for preventing dietrelated chronic diseases: the impact of food processing. Adv Nutr (Bethesda, Md). 2015;6(6):629-38.

260. Scientific Steering Committee of the Norwegian Scientific Committee for Food Safety: Comparison of organic and conventional food and food production. Overall summary: impact on plant health, animal health and welfare, and human health; 2014. https://vkm.no/download/18. 13735ab315cffecbb5138642/1501774854136/7852b1a164.pdf. Accessed 12 Oct 2017

261. European Parliament and Council of the European Union: Directive 2009/ 128/EC of the European Parliament and of the Council of 21 October 2009 establishing a framework for Community action to achieve the sustainable use of pesticides. Eur-Lex 2009.

262. Sofi F, Macchi C, Abbate R, Gensini GF, Casini A. Mediterranean diet and health status: an updated meta-analysis and a proposal for a literaturebased adherence score. Public Health Nutr. 2014;17(12):2769-82.

263. UNEP: Avoiding future famines: strengthening the ecological foundation of food security through sustainable food systems. 2012.

264. Dernini S, Berry EM. Mediterranean diet: from a healthy diet to a sustainable dietary pattern. Front Nutr. 2015;2:15.

265. Sáez-Almendros S, Obrador B, Bach-Faig A, Serra-Majem L. Environmental footprints of Mediterranean versus western dietary patterns: beyond the health benefits of the Mediterranean diet. Environ Health. 2013;12(1):118.

266. Mithril C, Dragsted LO, Meyer C, Blauert E, Holt MK, Astrup A. Guidelines for the new Nordic diet. Public Health Nutr. 2012;15(10):1941-7.

267. Mithril C, Dragsted LO, Meyer C, Tetens I, Biltoft-Jensen A, Astrup A. Dietary composition and nutrient content of the new Nordic diet. Public Health Nutr. 2013;16(05):777-85.

268. Saxe $H$. The new Nordic diet is an effective tool in environmental protection: it reduces the associated socioeconomic cost of diets. Am J Clin Nutr. 2014;99(5):1117-25.

269. Poulsen SK, Due A, Jordy AB, Kiens B, Stark KD, Stender S, Holst C, Astrup A, Larsen TM. Health effect of the new Nordic diet in adults with increased waist circumference: a 6-mo randomized controlled trial. Am J Clin Nutr. 2014;99(1):35-45.

270. Strassner C, Cavoski I, Di Cagno R, Kahl J, Kesse-Guyot E, Lairon D, Lampkin $\mathrm{N}$, Loes AK, Matt D, Niggli U, et al. How the organic food system supports sustainable diets and translates these into practice. Front Nutr. 2015;2:19.

271. Moomaw W, Griffin T, Kurczak K, Lomax J. The critical role of global food consumption patterns in achieving sustainable food systems and food for all. In: United Nations Environment Programme, Tech Rep; 2012.

\section{Submit your next manuscript to BioMed Central and we will help you at every step:}

- We accept pre-submission inquiries

- Our selector tool helps you to find the most relevant journal

- We provide round the clock customer support

- Convenient online submission

- Thorough peer review

- Inclusion in PubMed and all major indexing services

- Maximum visibility for your research

Submit your manuscript at www.biomedcentral.com/submit 